Article

\title{
Effect of Elapsed Time after Mixing on the Strength Properties of Lime-Iron Ore Tailings Treated Black Cotton Soil as a Road Construction Material
}

\author{
Annafi Qaudri Babatunde ${ }^{1}$, Eberemu Adrian Oshioname ${ }^{2, *} \mathbb{B}$, Yohanna Paul $^{3}$ and \\ Osinubi Kolawole Junwolo ${ }^{1}$ \\ 1 Department of Civil Engineering, Ahmadu Bello University, Zaria 810001, Nigeria; \\ annbiz2001@yahoo.com (A.Q.B.); kjosinubi@abu.edu.ng (O.K.J.) \\ 2 Department of Civil Engineering, Africa Centre of Excellence on New Pedagogies in Engineering Education, \\ Ahmadu Bello University, Zaria 810001, Nigeria \\ 3 Department of Civil Engineering, University of Jos, Jos 930001, Nigeria; ngadinap@unijos.edu.ng \\ * Correspondence: aoeberemu@abu.edu.ng
}

Received: 31 July 2020; Accepted: 24 September 2020; Published: 25 October 2020

\begin{abstract}
The study evaluated the effect of elapsed time after mixing on the strength properties of lime and iron ore tailings (IOT) treated black cotton soil (BCS) (an expansive tropical black clay) as road construction material. BCS was treated with $0,2,4,6$, and $8 \%$ lime and $0,2,4,6,8$, and $10 \%$ IOT content by dry weight of soil. Tests carried out include Atterberg limits, compaction, unconfined compressive strength (UCS), California bearing ratio (CBR) (unsoaked condition), and microstructure of specimens. Statistical analysis was done using MINI-TAB software. Results show that the liquid limit (LL) of BCS-lime-IOT mixtures decreased with increase in lime and IOT content. The LL values of all the treated BCS increased between 0 and $1 \mathrm{~h}$ elapsed time after mixing. On the other hand, the plastic limit (PL) of BCS decreased with increase in lime and IOT content while the plasticity index (PI) decreased from 27.7 to $22.9 \%$ for $0 \%$ lime/0\% IOT content and from 30.6 to $26.6 \%$ for $0 \%$ lime/10\% IOT content. Maximum dry density (MDD) of BCS increased while optimum moisture content (OMC) decreased with higher IOT content. The natural BCS recorded OMC value of $25.6 \%$ decreased to $15.2 \%$ for $8 \%$ lime/10\% IOT treatment. The strength (i.e., UCS and CBR values) increased with increase in lime/IOT contents between 0 and $2 \mathrm{~h}$ elapsed time after mixing. Peak values were recorded for $8 \%$ lime/8\% IOT treatment for all lime content considered. Regression analysis shows a strong relationship between the strength properties and the soil parameters. An optimal 8\% lime/8\% IOT treatment of BCS for elapsed time after mixing not exceeding $2 \mathrm{~h}$ was established and is recommended as sub-base material for low-trafficked roads.
\end{abstract}

Keywords: California bearing ratio; compaction; elapsed time after mixing; iron ore tailings; lime; road construction material; unconfined compressive strength

\section{Introduction}

Civil engineering construction works are sometime subjected to construction delays that might be caused by several factors such as human error, machine breakdown, or environmental factors. Construction delays most times include elapsed time after mixing/placing because of any of the following reasons: sudden rain; breakdown of compaction equipment after mixing; insufficient workers; poor transportation, and so forth. Thus elapsed time after mixing before compaction might affect workability and the density/strength properties of the compacted soil in the field. The need to study the impact of such delays is essential to achieve desired results in the field. Several studies on the effect of elapsed time after mixing are reported in the literatures [1-6]. Apart from delays during 
construction, some soils such as black cotton soils, which are expansive in nature, are not suitable in their natural state for use for some construction purposes and need to be improved. The necessity for improving black cotton soils is based on the predominance of the soil in the northeast region of the country and other parts of the world. Removal of the soil prior to road construction is not economically viable, hence the need for the improvement.

Black cotton soils (BCS) occupy an estimated $104,000 \mathrm{~km}^{2}$ in the northeast region of Nigeria [7]. They are a product of disintegrating shale and argillaceous deposits as well as volcanic rocks. They have more of montmorillonite which exhibits expansion and contraction behavior, with adjustment in water content. The shrink-swell nature of the soil when in contact with water could result in pavement failure manifesting as displacement, cracks, and depressions. Construction of roads on expansive soil is problematic since there is the possibility of expansion and contraction with adjustment in water, due to the presence of montmorillonite [7-10]. Improvement of such soil is a cheaper alternative to replacing it in the field, hence the need for the use of various additives such as cement, lime, and industrial and agricultural waste with pozzolanic potential prior to field application.

Researchers [11-14] reported improved plasticity, workability, and stability characteristics of fine-grained soil with the addition of small quantities of lime. The engineering characteristics of BCS were improved with lime, cement, and other admixtures [15]. These methods have been successfully used in road, railroad, and airport works to enhance subgrades and sub-bases. Usually inclusion of lime and cement for the improvement of weak soils is needed but costly [7,16-19]. Lime has been confirmed to be a supplement that beneficially enhances the engineering characteristics of nongranular soils. It has also been confirmed that the extent of dispersed double layers is reduced with inclusion of lime due to increase in the combining power of transposable ion or the electrolyte cluster [15,20-22].

Industrial and agricultural wastes cause air and water pollution and they occupy usable space; therefore, management of waste such as tailings is beneficial, not just for pollution control but also for the preservation of the environment. Tailings are stockpiled and they form embankments which can be eroded, cut down, or completely breached $[15,18,21,23,24]$. Iron ore tailings (IOTs) are the wastes obtained from the beneficiation of mined iron ore. In Nigeria, about 3072 tons/day are mined at Itakpe mines [25]. The total world production of iron ore in 2014 was 3.22 billion tons and for each ton of beneficiated iron ore, it is estimated that about $40 \%$ of tailings are produced [26]. Tailings have been used as supplementary materials for concrete works [27]. Mine tailings (e.g., iron ore tailings, IOTs) can be beneficially used in civil engineering construction works, thereby reducing the disposal issues and environmental threats associated with them $[19,28]$. The index characteristics of BCS have been improved with mine tailings $[15,21]$.

Studies have been carried out using IOTs alone [29,30] and as admixture [31] in lime or cement improvement of BCS. However, little attention has been given to the study of the allowable delay between mixing of the soil with the additives and subsequent placement as well as compaction. Wastes from the mining industry have to be managed by finding cost-effective and economic ways to beneficially reuse them, thereby reducing problems associated with waste disposal. This study was focused on the improvement of BCS with lime using IOTs as admixture for elapsed time after mixing of up to $3 \mathrm{~h}$. The objective was to determine the effect of elapsed time after mixing for an optimal formulation for road construction material (or equivalent).

\section{Materials and Methods}

\subsection{Materials}

Soil: The BCS used was obtained from Deba, Gombe State, Nigeria, located between latitude $10^{\circ} 13^{\prime}$ and $10^{\circ} 2^{\prime}$ north and longitude $11^{\circ} 23^{\prime}$ and $11^{\circ} 38^{\prime}$ east.

Lime: Lime was obtained as a commercial product from an open market in Kaduna, Kaduna state, Nigeria. 
Iron ore tailings: The IOTs were collected from the premises of the National Ore Mining Company, Itakpe in Kogi state, Nigeria. Only IOTs that passed through a $75 \mu \mathrm{m}$ sieve were used in this study.

\subsection{Methods}

Index properties: All tests were done in accordance with procedures outlined in BS 1377 [32] and BS 1377 [33] for the natural soil and modified soil, respectively. Lime was used at stepped concentration of $0,2,4,6$, and $8 \%$ for $0,2,4,6,8$, and $10 \%$ IOT, by dry weight of the soil sample at $0-2$ and 3 h elapsed time after mixing. Sample size of 120 was used for the statistical analysis (i.e., regression) for varying proportion of additives and elapsed time considered.

Plasticity properties: The Atterberg limits tests (i.e., liquid limits, plastic limits, and plasticity index) were carried out on the natural and treated soil in accordance with the procedures outlined in BS 1377 [32].

Compaction: The natural and treated soils were compacted with British Standard light (BSL) energy (also called proctor energy) in accordance with BS 1377 [32]. The soil sample was thoroughly mixed before compaction with $596 \mathrm{kN} / \mathrm{m}^{3}$ proctor energy in 3 layers with 27 blows using $2.5 \mathrm{~kg}$ rammer dropping from a height of $300 \mathrm{~mm}$ for each of the layers in a $1000 \mathrm{~cm}^{3}$ mold. The compacted soil was extruded from the mold into the large wide tray and crushed again before adding more water content and the procedure was repeated until the weight of the compacted soil reduced. For the consideration of elapsed time after mixing, the natural and treated soil, the lime, and the IOT were added in the concentrations stated above and water content was added. Each treated soil sample was placed in a polythene bag, sealed, and left for $0-2$ and $3 \mathrm{~h}$ before the compaction test. The moisture content was determined and result plotted on graphs. The plotted graphs gave the maximum dry density (MDD) and the corresponding optimum moisture content (OMC).

Unconfined compressive strength: The unconfined compressive strength (UCS) tests were carried out on the natural and treated soil samples compacted at their OMCs using BSL energy as described above in accordance with BS 1377 [32]. Cylindrical specimens with a diameter of $38 \mathrm{~mm}$ and a length of $76 \mathrm{~mm}$ were cored from the extruded compacted soil and each cured for seven days. After curing, specimens were tested on a UCS strain-controlled compression testing machine. The axial deformations and forces at regular intervals before failure were taken and recorded. The recorded data were plotted on the stress-strain curve and the UCS was determined as the point of failure. The UCS was calculated using Equations (1) and (2):

$$
\sigma=\frac{R \times C_{r} \times(100-\varepsilon \%) \times 1000 \mathrm{kN} / \mathrm{m}^{2}}{100 \times A_{0}}
$$

where:

$$
\varepsilon \%=\frac{v}{L_{0}}
$$

$\varepsilon \%$ is the strain percent, $v$ is the amount of deformation at any stage $(\mathrm{mm}), \mathrm{R}$ is the load ring reading at strain $\varepsilon, C_{r}$ is the mean calibration of load ring, $L_{\mathrm{O}}$ is the original length of specimen $(\mathrm{mm}), \mathrm{A}_{\mathrm{o}}$ is the original cross-sectional area $\left(\mathrm{mm}^{2}\right)$, and $\sigma$ is the compressive stress at strain $\varepsilon\left(\mathrm{kN} / \mathrm{m}^{2}\right)$.

California bearing ratio: The California bearing ratio (CBR) was carried out on the natural and lime/IOT-treated BCS according to procedures outlined in BS 1377 [32] and BS 1377 [33] respectively. Soil samples were blended with lime/IOT at their OMC, placed in polythene bags, and left for 0-2 and $3 \mathrm{~h}$ before compaction in $2350 \mathrm{~cm}^{3}$ molds in three (3) layers applying 62 blows to each layer from a $2.5 \mathrm{~kg}$ rammer. The molds were then immersed in water for a period of $24 \mathrm{~h}$ prior to testing as specified by Nigerian General Specifications [34] Equation (3) was used to compute the CBR values.

$$
\text { CBR }(\%)=\frac{\text { Measured Load }}{\text { Standard Load }} \times 100
$$

Standard load: $13.24 \mathrm{kN}$ at $2.5 \mathrm{~mm}$ after penetration and $19.96 \mathrm{kN}$ at $5.0 \mathrm{~mm}$ after penetration. 


\section{Results and Discussion}

\subsection{Index Properties}

The preliminary tests conducted on the natural BCS in accordance with BS 1377 [32] indicated that the soil was fine-grained with a moisture content of $11.9 \%$. The soil had liquid limit of $60.3 \%$, plastic limit of $32.6 \%$, and plasticity index of $27.7 \%$. The soil was classified as $\mathrm{CH}$ [35] or A-7-6(14) [36]. Previous reports by similar authors (i.e., [15] and [37] showed that montmorillonite was the dominant clay mineral in the soil while specific gravity of 2.29 fell close to the previously reported values. The properties are summarized in Table 1, while the oxide composition of the additives (i.e., lime and IOT) are given in Table 2.

Table 1. Properties of the natural black cotton soil.

\begin{tabular}{|c|c|c|}
\hline \multicolumn{2}{|l|}{ Property } & \multirow{2}{*}{$\frac{\text { Quantity }}{67.9}$} \\
\hline Percentage passing sieve No. 200 (0.075 mm) (\%) & Natural moisture content $(\%)$ & \\
\hline & & 11.9 \\
\hline Liquid limit (\%) & & 60.3 \\
\hline Plastic limit (\%) & & 32.6 \\
\hline Plasticity index $(\%)$ & & 27.7 \\
\hline Specific gravity & & 2.29 \\
\hline AASHTO classification & & A-7-6 (14) \\
\hline USCS & & $\mathrm{CH}$ \\
\hline Maximum dry density $\left(\mathrm{Mg} / \mathrm{m}^{3}\right)$ & & 1.47 \\
\hline Optimum moisture content (\%) & & 25.6 \\
\hline Unconfined compressive strength $\left(\mathrm{kN} / \mathrm{m}^{2}\right)$ & & 163.31 \\
\hline California bearing ratio (unsoaked) $(\%)$ & & 3 \\
\hline Color & & Dark grey \\
\hline Dominant clay mineral & & Montmorillonite \\
\hline
\end{tabular}

Table 2. Chemical properties of iron ore tailings.

\begin{tabular}{ccc}
\hline Oxide & Percentage ${ }^{*}$ Lime & $\begin{array}{c}\text { By Mass } \\
\text { Iron Ore Tailings }\end{array}$ \\
\hline Silica $\left(\mathrm{SiO}_{2}\right)$ & 0.35 & 45.64 \\
Iron Oxide $\left(\mathrm{Fe}_{2} \mathrm{O}_{3}\right)$ & 0.14 & 47.7 \\
Allumina $\left(\mathrm{Al}_{2} \mathrm{O}_{3}\right)$ & 0.6 & 3.36 \\
Lime $(\mathrm{CaO})$ & 54.92 & 0.607 \\
Magnesium Oxide $(\mathrm{MgO})$ & - & 0.393 \\
Manganese Oxide $(\mathrm{MnO})$ & 0.09 & 0.067 \\
Nickel Oxide $\left(\mathrm{NiO}_{2}\right)$ & & - \\
Tin Oxide $\left(\mathrm{TiO}_{2}\right)$ & & 0.24 \\
Copper Oxide $(\mathrm{CuO})$ & & - \\
Barium Oxide $\left(\mathrm{BaO}^{2}\right)$ & & - \\
Cadmium Oxide $(\mathrm{CdO})$ & 0.02 & 0.405 \\
Alkali $\left(\mathrm{Na}_{2} \mathrm{O}\right)$ & 0.04 & 0.607 \\
Alkali $\left(\mathrm{K}_{2} \mathrm{O}\right)$ & & - \\
Yttrium Oxide $\left(\mathrm{Y}_{2} \mathrm{O}_{3}\right)$ & 0.06 & - \\
Sulphur Oxide $\left(\mathrm{SO}_{3}\right)$ & 0.05 & \\
Vanadium Oxide $\left(\mathrm{V}_{2} \mathrm{O}_{5}\right)$ & 43.67 & - \\
Loss on Ignition & & \\
\hline
\end{tabular}

* [38] Bernard (2011) ** [29] Ishola (2014). 


\subsection{Atterberg Limits}

\subsubsection{Liquid Limit}

Effect of admixtures on liquid limit.

The variation of LL of BCS-lime mixtures with IOT content is presented in Figure 1a-d. The LL of BCS-lime-IOT mixtures decreased with an increase in the lime and IOT contents. This may be attributed to the decrease in the silt and clay fractions because of agglomeration and flocculation of the particles. This could be linked to cation exchange reactions whereby $\mathrm{Ca}^{2+}$ in IOT and lime reacted with lower valence ions present in the clay structure $[15,21,37]$. The addition of lime and IOT introduced $\mathrm{Ca}^{2+}$ needed for strength which triggered a decrease in the repulsive force of the soil mixture, thus requiring additional water for the soil to reach its dynamic shear strength [39]. In other words, calcium ions $\left(\mathrm{Ca}^{2+}\right)$ and hydroxides $\left(\mathrm{OH}^{-}\right)$produced by the addition of lime to the soil water system combined with silica $(\mathrm{Si})$ and alumina $(\mathrm{Al})$ in the clay fraction to form calcium silicate hydrates and calcium aluminate hydrates [13]. The experimental studies reported in the literature [40-43] generally showed that inclusion of lime to clay soils reduces the LL. A similar trend was reported by Phani Kumar and Sharma [44].

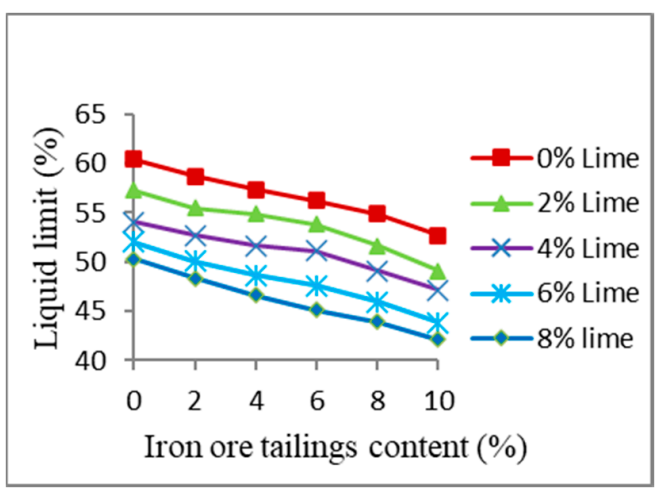

(a)

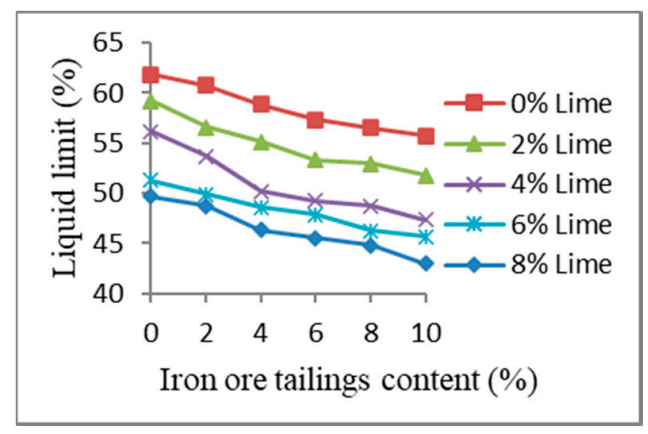

(c)

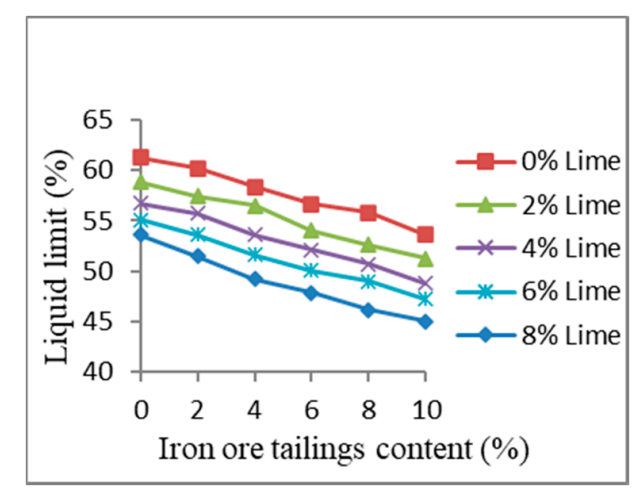

(b)

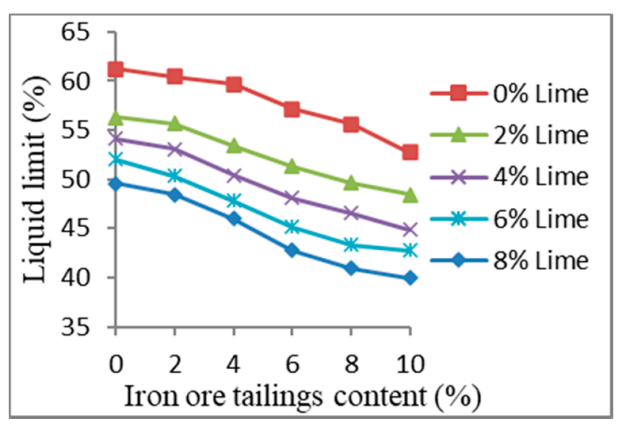

(d)

Figure 1. Variation of liquid limit of BCS-lime mixtures with IOT content for different elapsed times after mixing: (a) $0 \mathrm{~h}$, (b) $1 \mathrm{~h}$, (c) $2 \mathrm{~h}$, (d) $3 \mathrm{~h}$.

Effect of elapsed time after mixing on liquid limit.

The effect of elapsed time after mixing on the liquid limit of BCS-lime-IOT mixtures for the optimally treated soil (i.e., BCS-8\% lime and up to $10 \%$ IOT) is shown in Figure $2 \mathrm{a}, \mathrm{b}$. The LL of specimens increased between 0 and $1 \mathrm{~h}$ elapsed time after mixing. However, for BCS- $0 \%$ lime mixed with up to $10 \%$ IOT, the LL values increased for delays up to $2 \mathrm{~h}$ before decreasing. In the case of optimal BCS- $8 \%$ lime mixed with up to $10 \%$ IOT, LL decreased after $1 \mathrm{~h}$ delay. The recorded decrease may be associated with the creation of coarser aggregate and additional flocculated particle arrangement associated with increasing calcium for strength with elapsed time and consequent requirement for water to bring the soil to its dynamic strength [39]. 


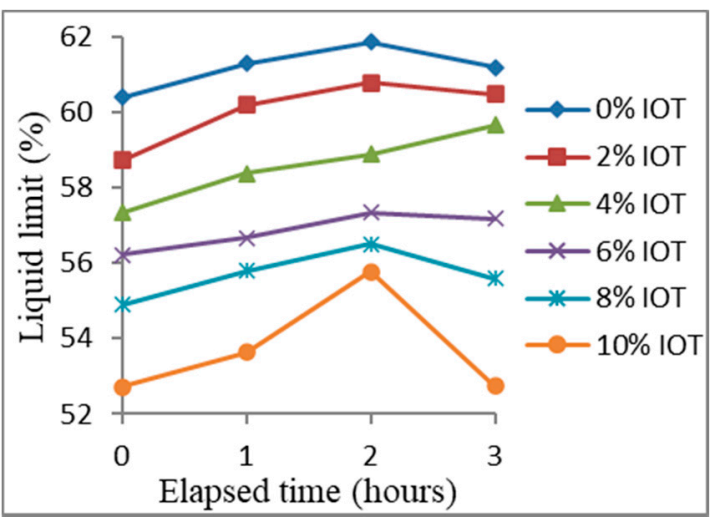

(a)

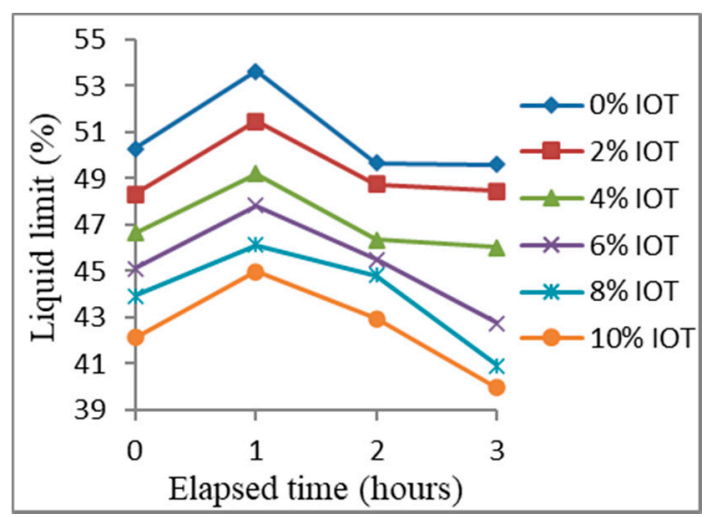

(b)

Figure 2. Variation of liquid limit of BCS with elapsed time after mixing for different blends: (a) $0 \%$ lime-IOT, (b) $8 \%$ lime-IOT.

\subsubsection{Plastic Limit}

Effect of admixtures on plastic limit.

The variation of plastic limit (PL) of BCS-lime-IOT mixtures at $0-3 \mathrm{~h}$ elapsed time after mixing is shown in Figure 3a-d. Generally, the PL of BCS decreased with an increase in lime and IOT content. The PL of BCS- $8 \%$ lime- $10 \%$ IOT mixture decreased from $32.6 \%$ to $16.4 \%$; from $38 \%$ to $19.9 \%$; from $37.8 \%$ to $19.1 \%$; and from $38.6 \%$ to $20.2 \%$ for $0-2$ and $3 \mathrm{~h}$ elapsed time after mixing, respectively. A similar trend was reported by researchers $[15,21,37,39,45,46]$. The decrease in PL might not be unconnected with the cation exchange reaction along with flocculation-agglomeration of clay particles from the addition of the additives.

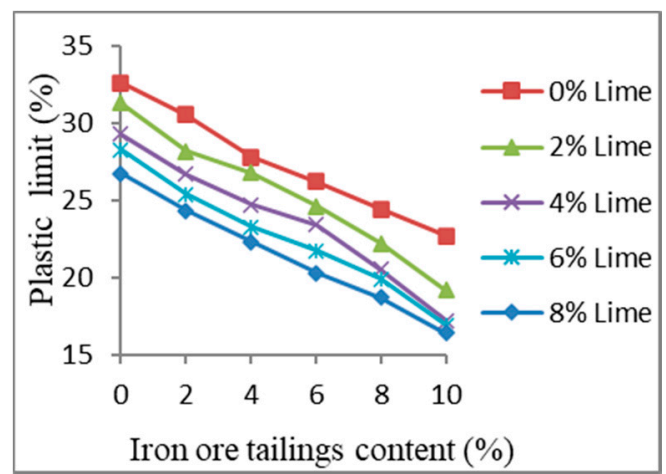

(a)

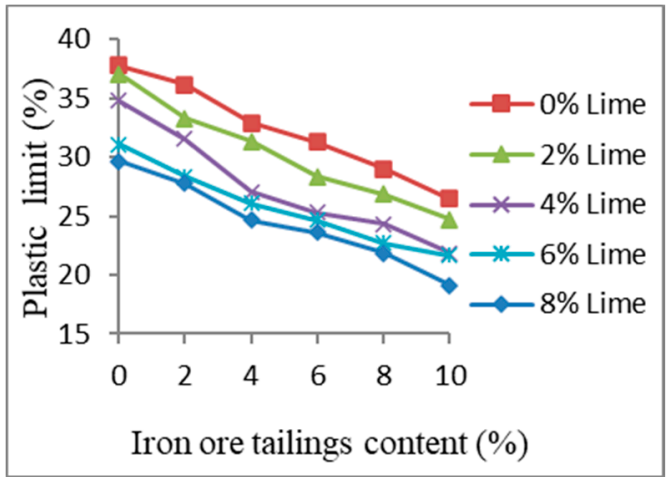

(c)

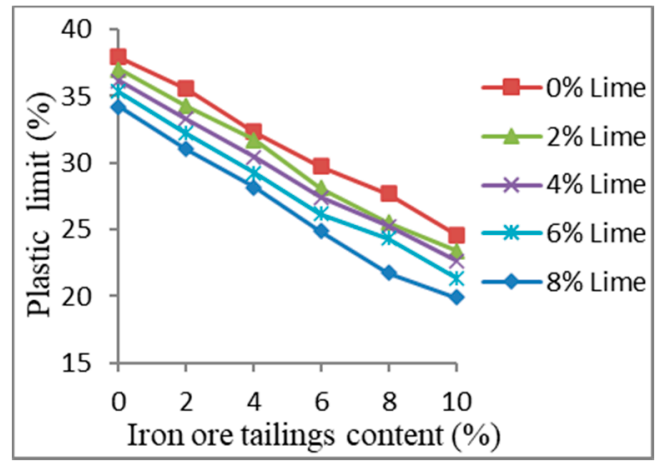

(b)

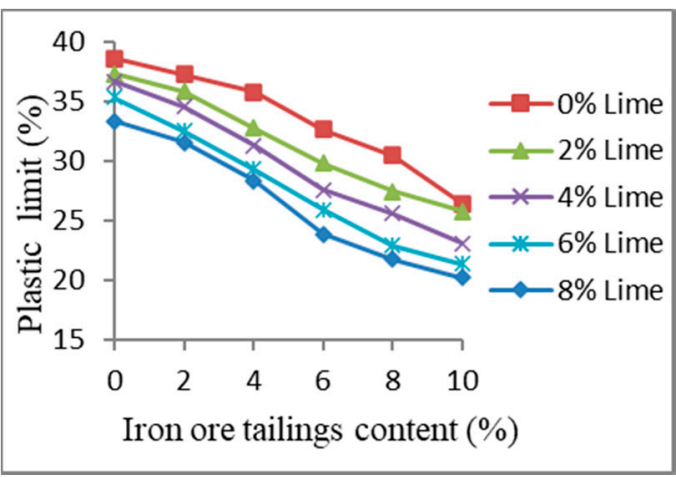

(d)

Figure 3. Variation of plastic limit of BCS-lime mixtures with IOT content for different elapsed times after mixing: (a) $0 \mathrm{~h}$, (b) $1 \mathrm{~h}$, (c) $2 \mathrm{~h}$, (d) $3 \mathrm{~h}$. 
Effect of elapsed time after mixing on plastic limit.

The variation of PL with elapsed time for BCS- $0 \%$ lime-up to $10 \%$ IOT mixtures and optimal BCS-8\% lime-up to $10 \%$ IOT mixtures is shown in Figure $4 a, b$. There was a general increase in PL for up to $3 \mathrm{~h}$ elapsed time after mixing for $0 \%$ lime-up to $10 \%$ IOT treatment while for the optimal $8 \%$ lime-up to $10 \%$ IOT treatment, a decrease was observed after $1 \mathrm{~h}$. PL values of 32.6, 38.0, 37.8, and 38.6 were obtained for $0-2$ and $3 \mathrm{~h}$, respectively, for $0 \%$ IOT $/ 0 \%$ lime. In the case of $0 \% \mathrm{IOT} / 8 \%$ lime treatment, PL values of 26.7, 34.4, 29.6, and 33.3 were recorded for the period of $0-2$ and $3 \mathrm{~h}$, respectively. Similar trends were observed for the remaining percentages of lime and IOT for both cases. The decrease in PL of the sample treated with lime (see Figure $4 \mathrm{~b}$ ) could be attributed to the continuous effect of lime (i.e., flocculation and agglomeration) on the BCS-IOT mixtures. The initial trend of increase in PL might be a result of the increased curing period that could have triggered the cation exchange, flocculation-agglomeration, and carbonation reactions to take place from lime and IOT. A similar trend was reported by other researchers [47-50].

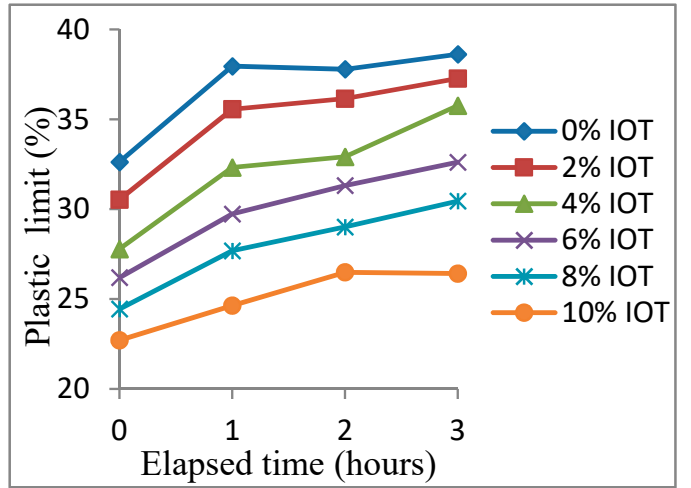

(a)

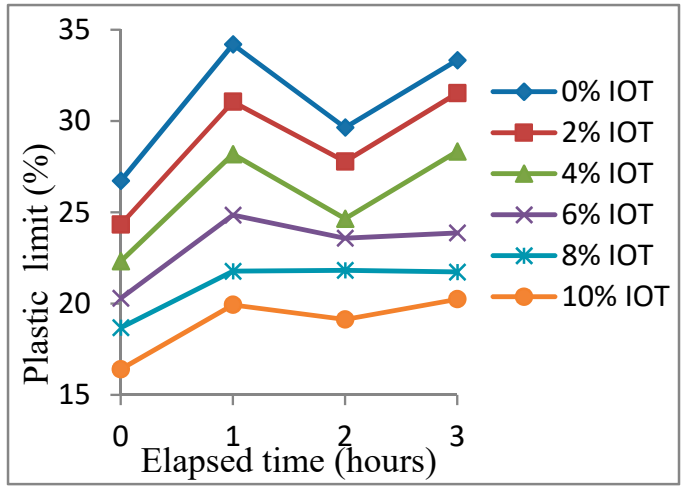

(b)

Figure 4. Variation of plastic limit of BCS with elapsed time after mixing for different treatments: (a) $0 \%$ lime-up to $10 \%$ IOT, (b) $8 \%$ lime-up to $10 \%$ IOT.

\subsubsection{Plasticity Index}

Effect of admixtures on plasticity index.

Plasticity index (PI) of BCS increased with an increase in IOT and decreased with an increase in lime content for varying delay periods (see Figure 5a-d). This reduction in PI with increase in lime content could be a result of replacement of the finer soil particles by the lime-IOT mixtures. The decrease in PI is in agreement with findings reported by Nwadiogbu [50] and Yisa [51] that indicate the improvement of the natural soil. Increase in PI with increase in IOT content is in agreement with the findings reported by Osinubi et al. [37].

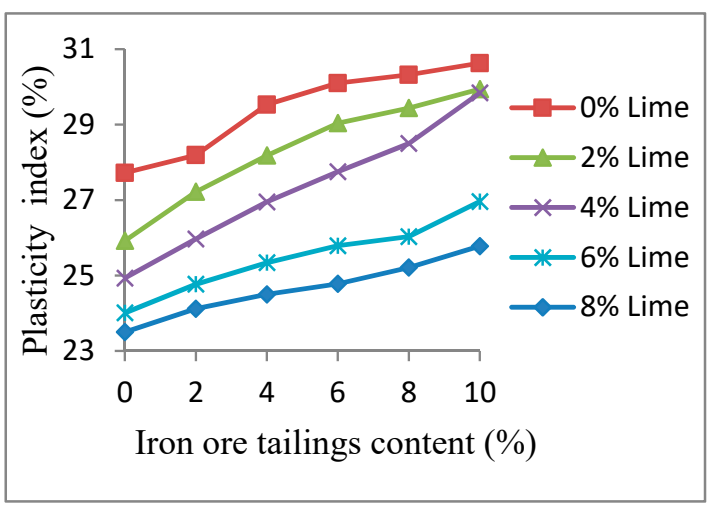

(a)

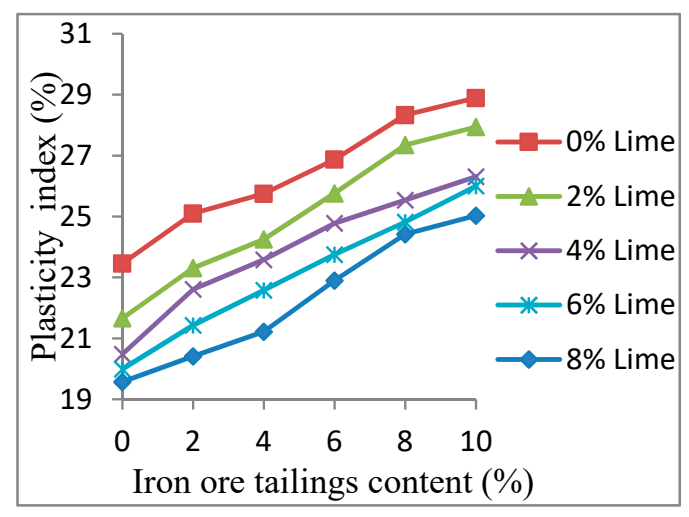

(b)

Figure 5. Cont. 


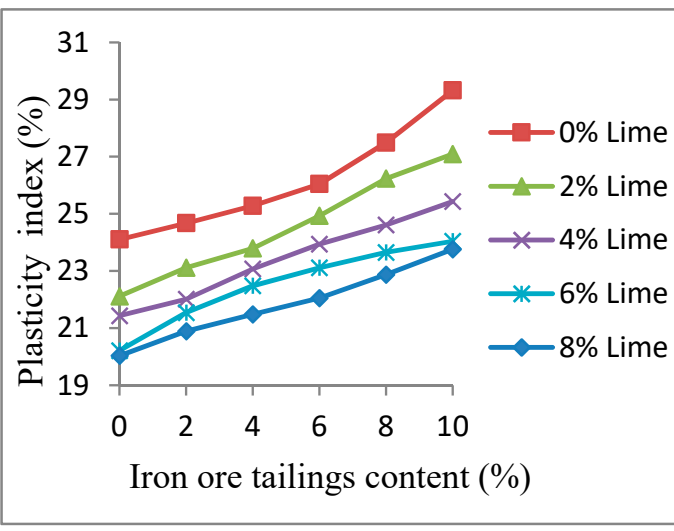

(c)

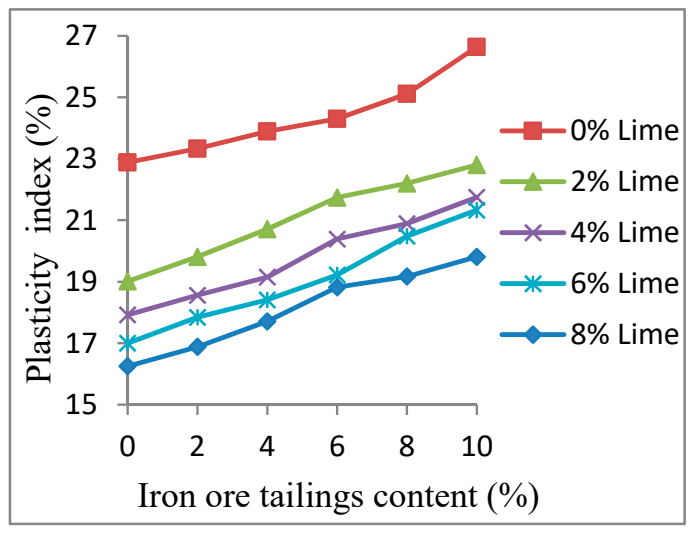

(d)

Figure 5. Variation of plasticity index of BCS-lime mixtures with IOT for different elapsed times after mixing: (a) $0 \mathrm{~h}$, (b) $1 \mathrm{~h}$, (c) $2 \mathrm{~h}$, (d) $3 \mathrm{~h}$.

Effect of elapsed time after mixing on plasticity index.

The variation of PI of BCS with elapsed time after mixing for $0 \%$ lime-up to $10 \%$ IOT and optimal $8 \%$ lime-up to $10 \%$ IOT treatment is shown in Figure $6 \mathrm{a}, \mathrm{b}$. Generally, $p$ value decreased with an increase in elapsed time after mixing up to $3 \mathrm{~h}$. The $p$ values decreased from 27.7 to $22.9 \%$ for $0 \%$ lime $/ 0 \%$ IOT and 30.6 to $26.6 \%$ for $0 \%$ lime/10\% IOT treatment. Similar trends with lower values were observed for specimens treated with $8 \%$ lime-up to $10 \%$ IOT (see Figure $6 \mathrm{~b}$ ) and were consistent with the findings reported by Nwadiogbu [50] and Yisa [51]. The reduction in $p$ value with elapsed time after mixing could be associated with the reduction in the hydration reaction of the lime when water was added to the soil $[6,52]$.

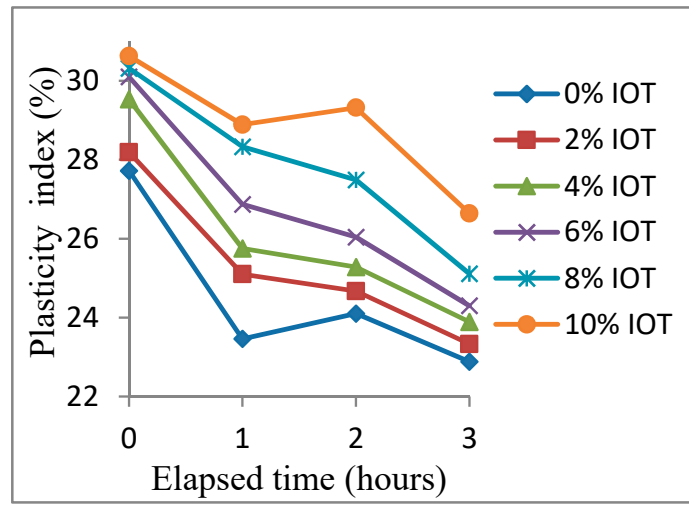

(a)

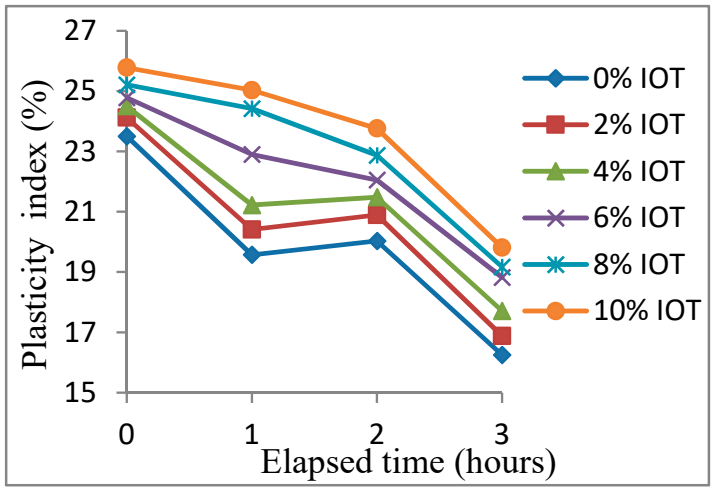

(b)

Figure 6. Variation of plasticity index of BCS with elapsed time after mixing for different treatments: (a) $0 \%$ lime-up to $10 \%$ IOT, (b) $8 \%$ lime-up to $10 \%$ IOT.

\subsection{Compaction Characteristics}

\subsubsection{Maximum Dry Density}

Effect of admixtures.

The variation of maximum dry density (MDD) of BCS-lime mixtures with IOT content for 0-3 h elapsed time after mixing is presented in Figure $7 \mathrm{a}-\mathrm{d}$. MDD value increased to a peak value at $8 \%$ IOT content and thereafter decreased at 10\% IOT content. However, it was observed that MDD decreased with higher lime content. MDD values increased from 1.47 to $1.52 \mathrm{Mg} / \mathrm{m}^{3}, 1.50$ to $1.55 \mathrm{Mg} / \mathrm{m}^{3}, 1.49$ to $1.54 \mathrm{Mg} / \mathrm{m}^{3}, 1.48$ to $1.55 \mathrm{Mg} / \mathrm{m}^{3}$, and 1.44 to $1.49 \mathrm{Mg} / \mathrm{m}^{3}$ for $0 \%$ lime-up to $8 \%$ IOT, $2 \%$ lime-up to $8 \%$ IOT, $4 \%$ lime-up to $8 \%$ IOT, $6 \%$ lime-up to $8 \%$ IOT, and $8 \%$ lime-up to $8 \%$ IOT treatment, respectively, 
for $0 \mathrm{~h}$ elapsed time after mixing. A similar trend was noticed for 1, 2, and $3 \mathrm{~h}$ elapsed time after mixing. The increase in MDD recorded may be due to the possible agglomeration and flocculation of clay particles mainly caused by cation exchange and also filling of voids in the soil skeleton by the admixtures which resulted in better packing and denser material $[15,53,54]$. Also, IOT with specific gravity (3.35) substituting the soil with lesser specific gravity (2.29) contributed to the development of a mixture with greater specific gravity and hence higher MDD $[29,55]$.

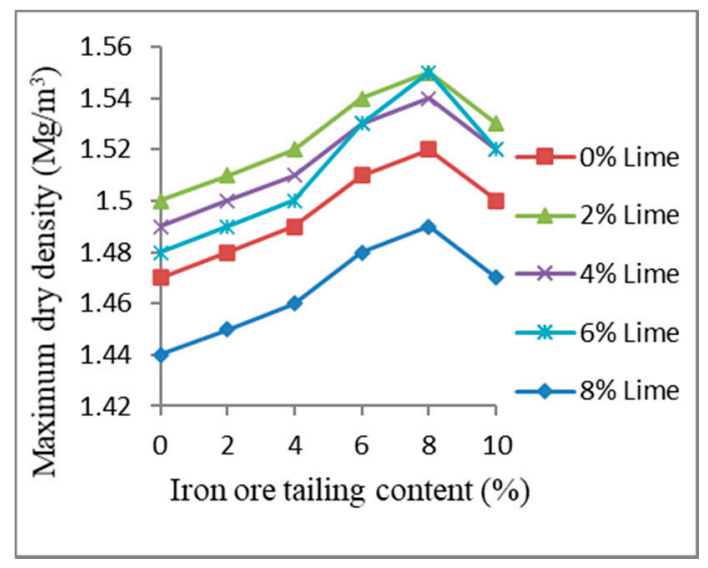

(a)

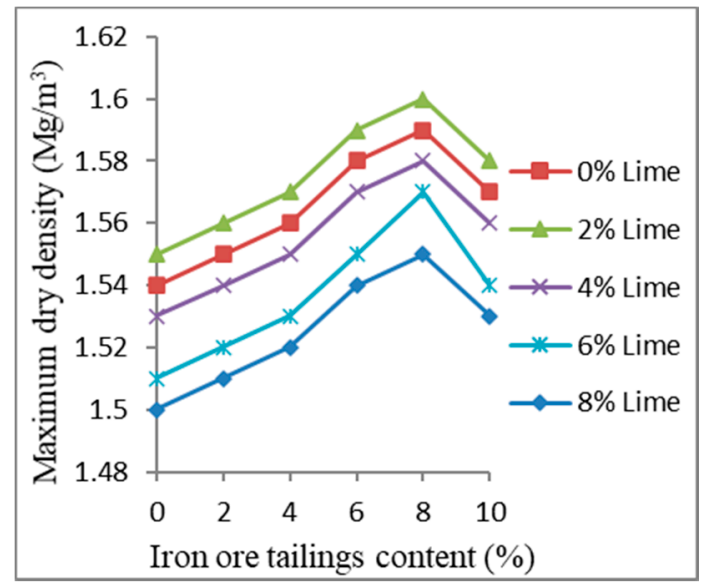

(c)

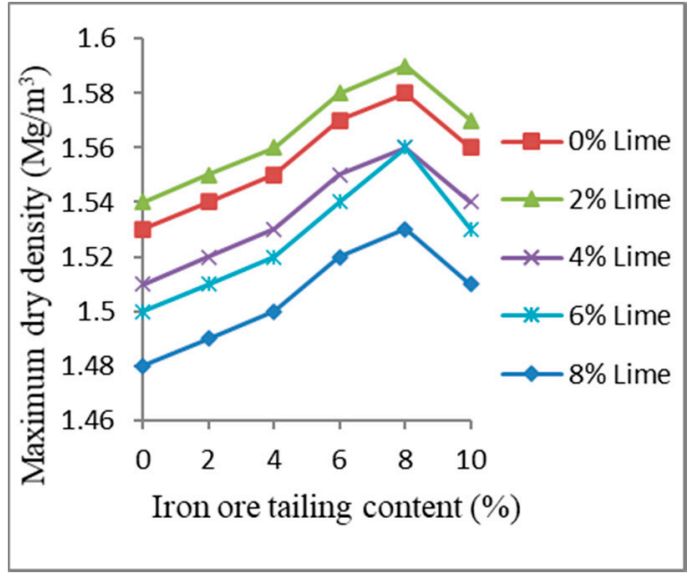

(b)

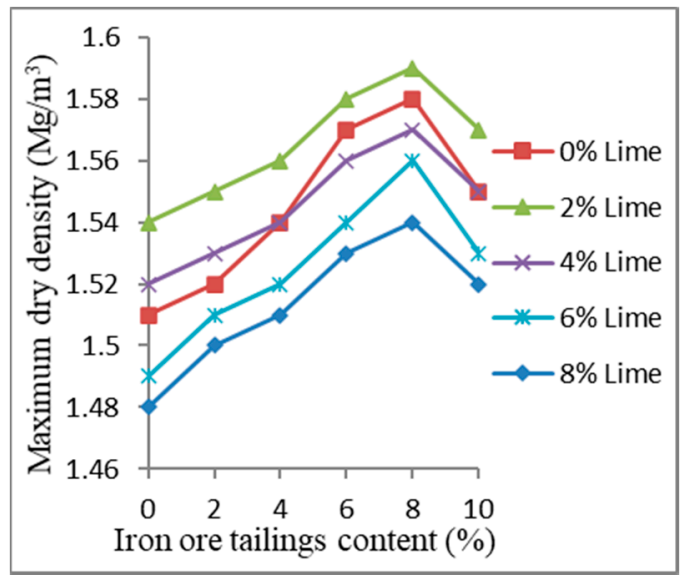

(d)

Figure 7. Variation of maximum dry density of BCS-lime mixtures with IOT content for different elapsed times after mixing: (a) $0 \mathrm{~h},(\mathbf{b}) 1 \mathrm{~h},(\mathbf{c}) 2 \mathrm{~h}$, (d) $3 \mathrm{~h}$.

Effect of elapsed time after mixing on MDD.

The variation of MDD of BCS with elapsed time after mixing for $0 \%$ lime-up to $10 \%$ IOT and optimal 8\% lime-up to 10\% IOT treatment is shown in Figure 8a-d. Generally, the MDD value increased for up to $2 \mathrm{~h}$ elapsed time after mixing for all the lime and IOT treatments considered before decreasing at $3 \mathrm{~h}$ elapsed time after mixing. A similar trend was reported by Abdullahi [48] and Nwadiogbu [50]. The MDD increased from 1.47 to $1.54 \mathrm{Mg} / \mathrm{m}^{3}$ for $0 \%$ lime $/ 0 \%$ IOT and 1.5 to $1.57 \mathrm{Mg} / \mathrm{m}^{3}$ for $0 \%$ lime $/ 10 \%$ IOT treatment. A similar trend was observed for $8 \%$ lime-up to $10 \%$ IOT treatment. The increase in MDD recorded with elapsed time after mixing may be due to the increase in the hydration and cation exchange reactions and the creation of cementations compounds of calcium silicate hydrate and calcium aluminate which probably resulted in an increase in MDD. Similar findings are reported in the literature [2-6]. 


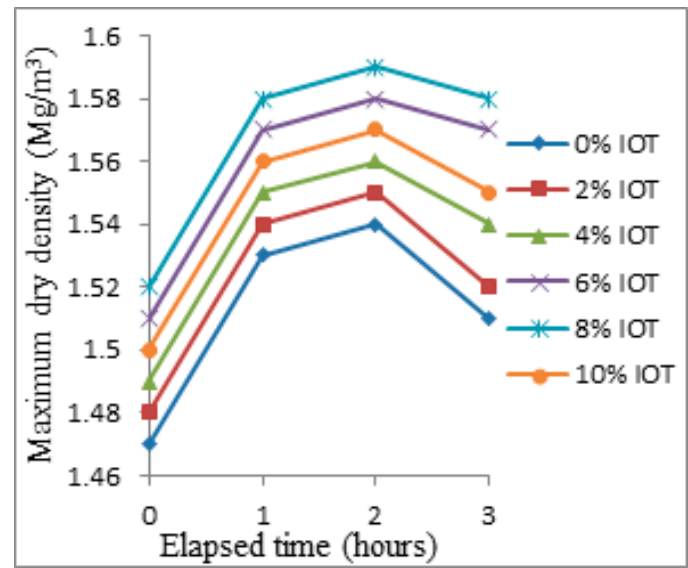

(a)

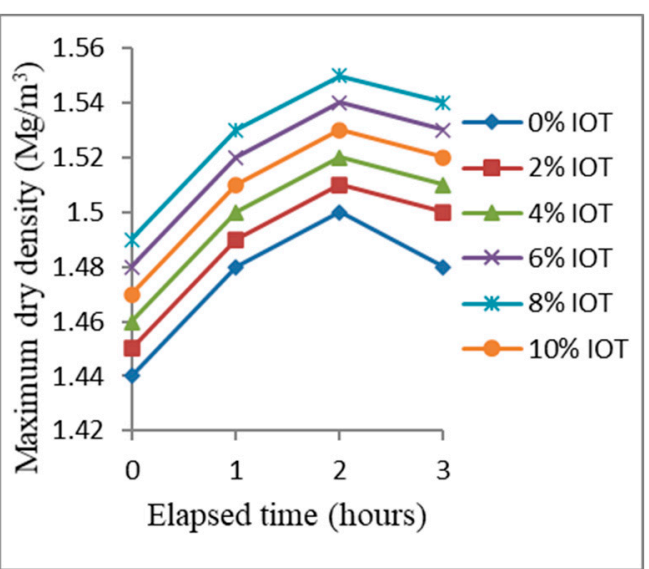

(b)

Figure 8. Variation of maximum dry density of BCS with elapsed time after mixing for different treatments: (a) $0 \%$ lime-up to 10\% IOT, (b) 8\% lime-up to $10 \%$ IOT.

\subsubsection{Optimum Moisture Content}

Effect of admixtures.

The variation of OMC of BCS-lime mixtures with IOT content for 0-3 h elapsed time after mixing is presented in Figure 9a-d. Generally, the OMC of BCS mixtures decreased with an increase in IOT content. OMC value for natural soil decreased from $25.62 \%$ to $15.20 \%$ at $8 \%$ lime/10\% IOT treatment. A similar trend was recorded for other lime/IOT treatments. The decrease in OMC may be linked to enhanced cation exchange reaction due to the combination of free lime products and the IOT that resulted in decreased thickness of the double layer causing flocculation.

As the clay flocculated, water separated from the particles became concentrated in the voids between the bonded particles, thus decreasing the OMC [49]. Also, the observed reduction in OMC may not be unconnected to self-desiccation, whereby water was used up, thus causing low hydration. When there was no water movement to or from the soil-lime-IOT matrix, the available moisture was used up in the hydration reaction, until too little was left to saturate the solid faces and therefore the relative humidity inside the paste decreased $[2,56,57]$.

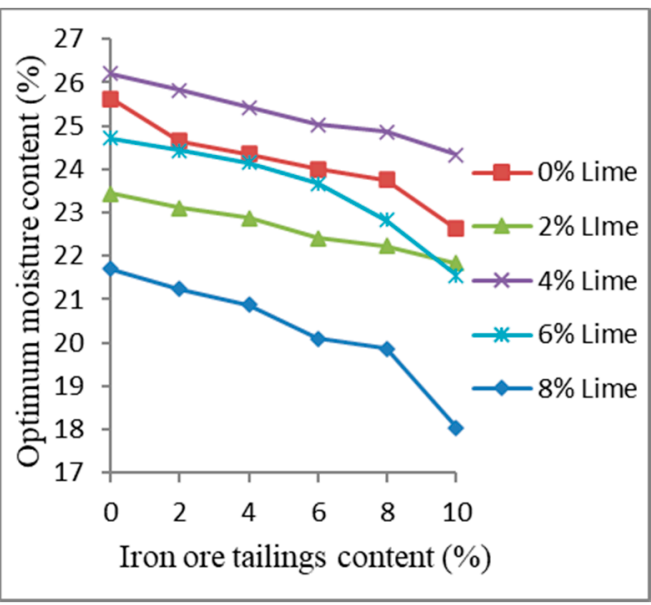

(a)

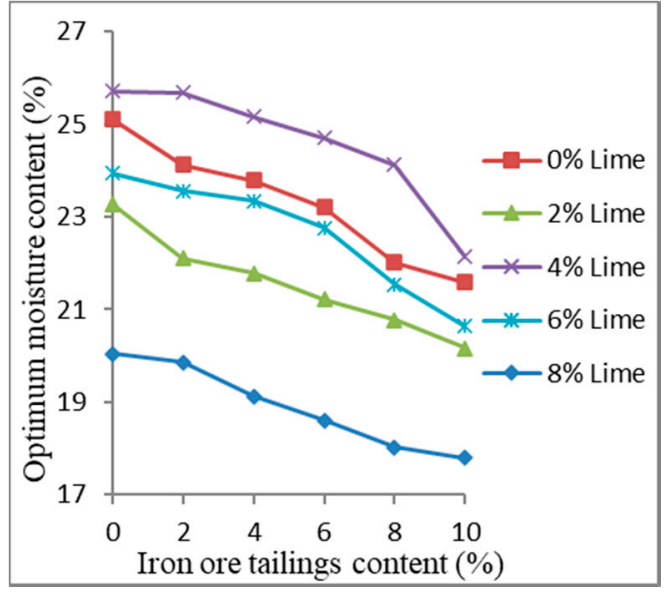

(b)

Figure 9. Cont. 


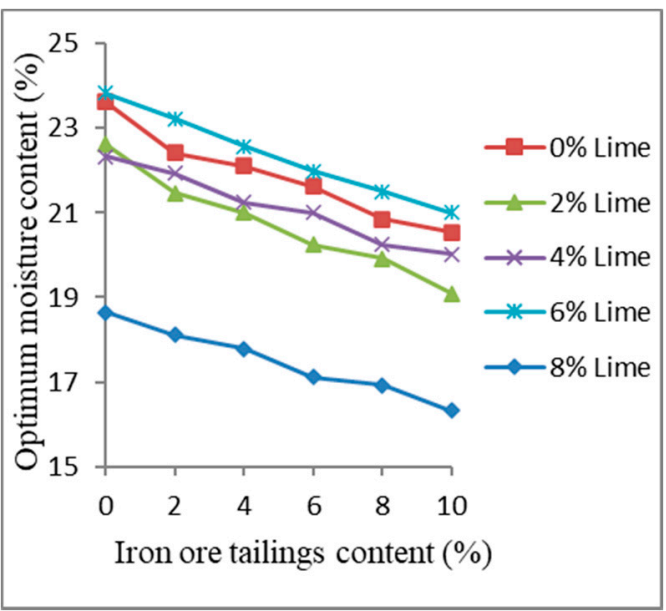

(c)

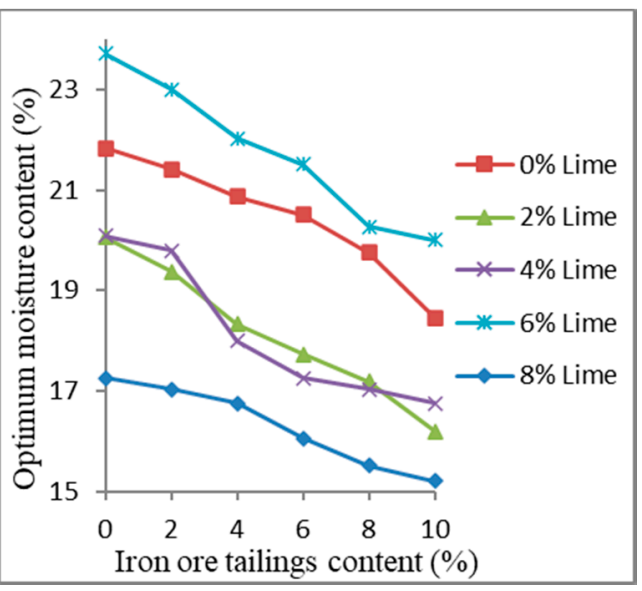

(d)

Figure 9. Variation of optimum moisture content of BCS-lime mixtures with IOT content for different elapsed times after mixing: (a) $0 \mathrm{~h},(\mathbf{b}) 1 \mathrm{~h},(\mathbf{c}) 2 \mathrm{~h}$, (d) $3 \mathrm{~h}$.

Effect of elapsed time after mixing.

The variation of OMC with elapsed time after mixing for $0 \%$ lime-up to $10 \%$ IOT and optimal $8 \%$ lime-up to $10 \%$ IOT treatment is shown in Figure 10a,b. Generally, OMC decreased with increased elapsed time after mixing for all the lime and IOT treatments considered. The OMC values decreased from 25.62 to $21.83 \%$ for $0 \%$ lime $/ 0 \%$ IOT and 22.63 to $18.46 \%$ for $0 \%$ lime $/ 10 \%$ IOT. A similar trend was observed for $8 \%$ lime-up to $10 \%$ IOT treatment. The reduction in OMC with elapsed time after mixing could be attributed to the increase in the hydration products formed with time that resulted in a decrease in OMC. Also, self-desiccation where the water was used up in the hydration process could be responsible for the decrease in OMC with elapsed time before compaction [4].

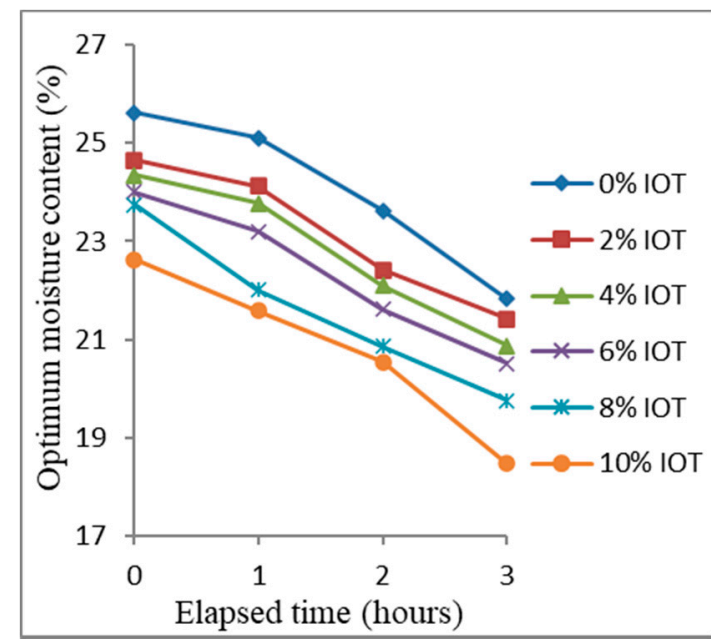

(a)

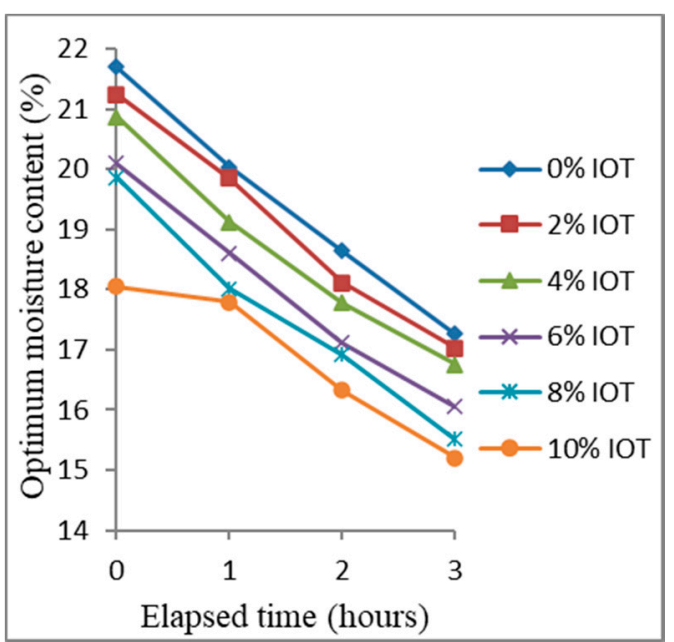

(b)

Figure 10. Variation of optimum moisture content of BCS with elapsed time after mixing for different treatments: (a) $0 \%$ lime-up to $10 \%$ IOT, (b) $8 \%$ lime-up to $10 \%$ IOT.

\subsection{Unconfined Compressive Strength (UCS)}

Effect of admixtures on UCS.

The variation of UCS of BCS-lime mixtures (seven days curing) with IOT content for different elapsed times after mixing is shown in Figure 11a-d. The UCS increased with an increase in both lime and IOT contents. For $0 \mathrm{~h}$ elapsed time after mixing, the UCS values increased from 84.2 to $217.2 \mathrm{kN} / \mathrm{m}^{2}$, 
153.5 to $526.6 \mathrm{kN} / \mathrm{m}^{2}, 307.8$ to $1071.3 \mathrm{kN} / \mathrm{m}^{2}, 413.0$ to $1459.1 \mathrm{kN} / \mathrm{m}^{2}$, and 622.1 to $1562.9 \mathrm{kN} / \mathrm{m}^{2}$ for $0 \%$ lime-0 up to $10 \%$ IOT, $2 \%$ lime-up to $10 \%$ IOT, $4 \%$ lime-up to $10 \%$ IOT, $6 \%$ lime-up to $10 \%$ IOT, and $8 \%$ lime-up to $10 \%$ IOT treatment, respectively. A similar trend was observed for 1, 2, and 3 h elapsed time after mixing. The improvement in UCS was probably due to the development of substances like calcium silicate hydrates (CSH), calcium aluminate hydrates $(\mathrm{CAH})$, and microfabric modifications, leading to strength development $[7,58,59]$. The exact products, however, varied with the kind of clay mineralogy and the reactions, including temperature, moisture, and curing conditions $[50,60,61]$. This reaction continued in the presence of moisture and could have been the reason for the increase in UCS with lime and IOT content with increased elapsed time. A reduction in the UCS values at 10\% IOT content for all the lime treatments was observed. The decrease in strength with the IOT content may be linked to excess IOT yielding lesser valence cations that could not be neutralized with the available greater valence cations. This reaction increased the affinity of $\mathrm{H}^{+}$which caused a drop in strength [62].

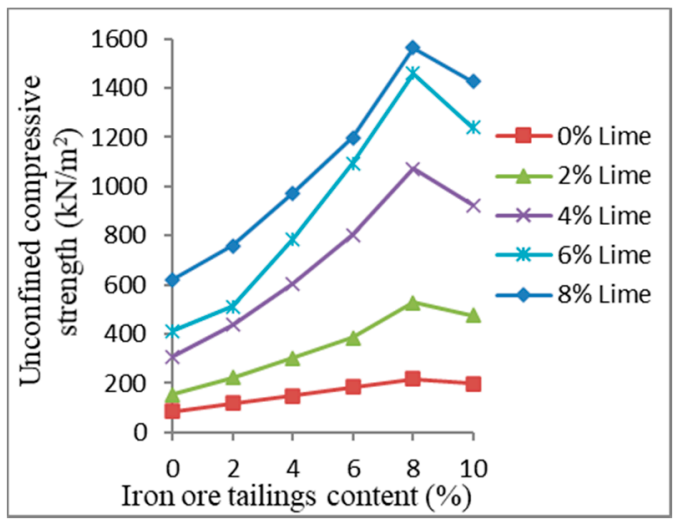

(a)

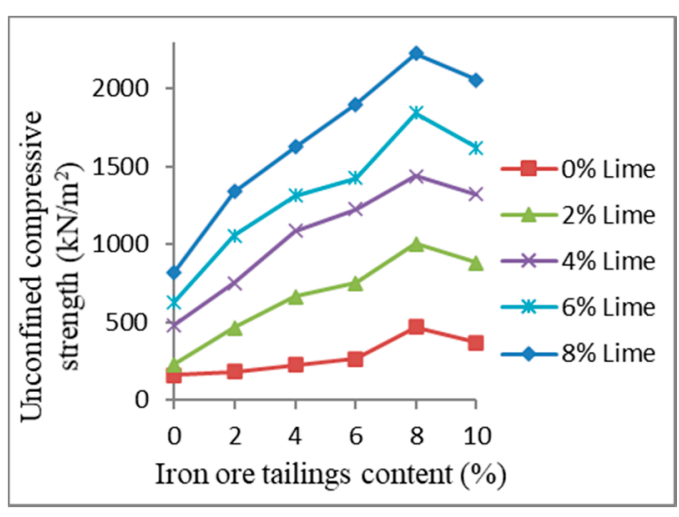

(c)

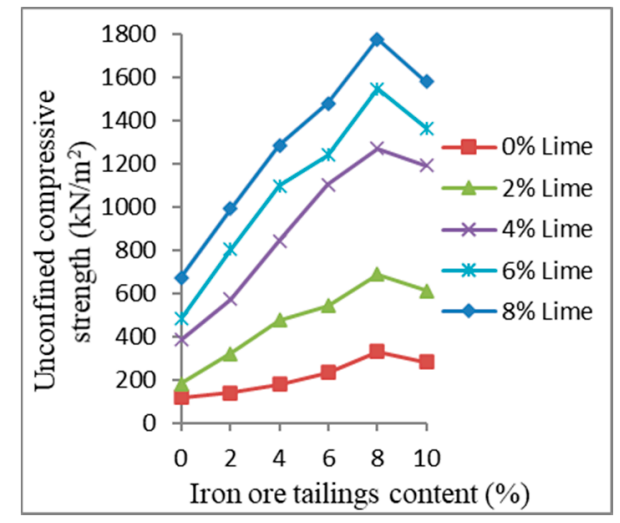

(b)

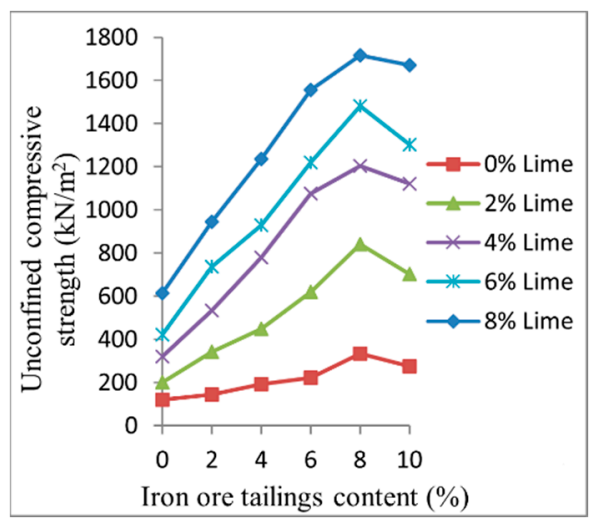

(d)

Figure 11. Variation of unconfined compressive strength of BCS-lime mixtures with IOT content for different elapsed times after mixing: (a) $0 \mathrm{~h}$, (b) $1 \mathrm{~h}$, (c) $2 \mathrm{~h}$, (d) $3 \mathrm{~h}$.

Effect of elapsed time after mixing on UCS.

The variation of UCS of BCS with elapsed time after mixing for $0 \%$ lime-up to $10 \%$ IOT and optimal $8 \%$ lime-up to $10 \%$ IOT treatment is shown in Figure 12a,b. The UCS value increased to peak values at $2 \mathrm{~h}$ elapsed time after mixing and thereafter decreased at $3 \mathrm{~h}$ elapsed time after mixing. The UCS values increased from 84.2 to $161.6 \mathrm{kN} / \mathrm{m}^{2}$ for $0 \%$ lime $/ 0 \%$ IOT and 196.8 to $369.9 \mathrm{kN} / \mathrm{m}^{2}$ for $0 \%$ lime $/ 10 \%$ IOT treatment. A similar trend was observed for optimal $8 \%$ lime-up to $10 \%$ IOT treatment. The early increase in the UCS for the first $2 \mathrm{~h}$ may be attributed to the fact that, once compaction is delayed, hydration processes that bind particles in their loose state are formed, thereby leading to aggregations of the soil particles and hence an increase in the density of the soil, which results 
in increased strength [4]. The decrease in UCS after a $3 \mathrm{~h}$ delay may be due to destruction of the cementitious bonds formed during the soil-lime-IOT reaction over the period between mixing and compaction. The destruction of this matrix during compaction results in a decline in the strength of the compacted soil. Ochepo [45] and Nwadiogbu [50] also reported improvement in the UCS and reduction at higher lime/IOT treatment.

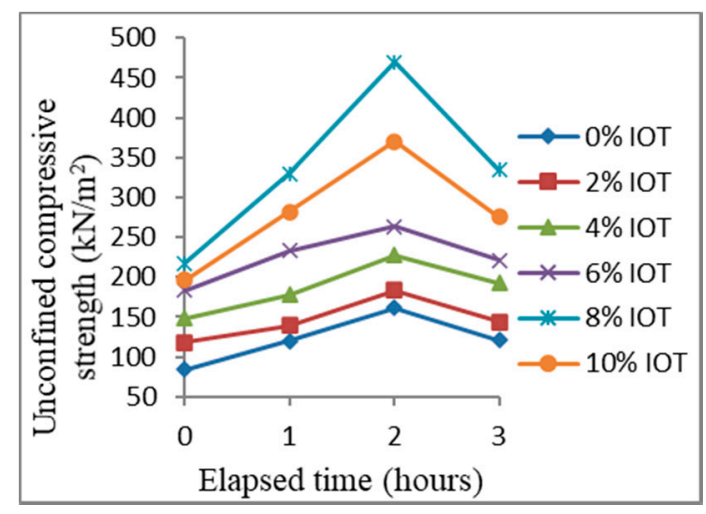

(a)

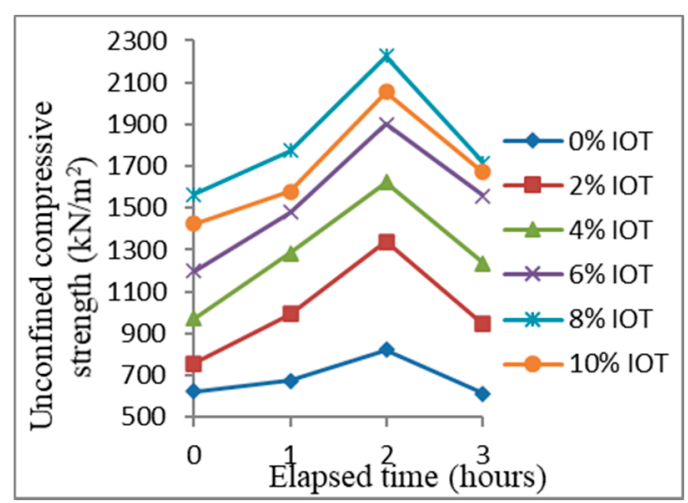

(b)

Figure 12. Variation of unconfined compressive strength of BCS with elapsed time after mixing for different treatments: (a) $0 \%$ lime-up to $10 \%$ IOT, (b) $8 \%$ lime-up to $10 \%$ IOT.

\subsection{California Bearing Ratio}

Effect of admixtures for unsoaked condition.

The California bearing ratio (CBR) value for unsoaked condition values of BCS-lime-IOT mixtures varied for different elapsed times after mixing is shown in Figure 13a-d. The CBR improved with increases in lime and IOT contents. Generally, peak CBR values were recorded at $8 \%$ lime $/ 8 \%$ IOT treatment before decreasing at $10 \%$ IOT for the lime content considered. For $0 \mathrm{~h}$ elapsed time, CBR values increased from 2.54 to $10.15 \%, 8.16$ to $40.06 \%, 16.31$ to $52.21 \%, 28.46$ to $84.28 \%$, and 43.32 to $104.23 \%$ for $0 \%$ lime- 0 up to $8 \%$ IOT, $2 \%$ lime- 0 up to $8 \%$ IOT, $4 \%$ lime- 0 up to $8 \%$ IOT, $6 \%$ lime-0 up to $8 \%$ IOT, and $8 \%$ lime -0 up to $8 \%$ IOT. A similar trend was noticed for 1-3 h elapsed time after mixing. However, $8 \%$ lime $/ 8 \%$ IOT treatment of BCS met the $80 \%$ requirement for base materials for unsoaked condition. The observed increase in CBR value was due to the development of cementitious substances like calcium silicate hydrates ( $\mathrm{CSH}$ ), calcium aluminates hydrates $(\mathrm{CAH})$, and hydrated lime due to the hydration of lime. The first two hydrates developed cementation linkages between these hydration products and soil particles regardless of the type of soil [7]. The hydrated lime released, however, reacted with pozzolanic iron ore tailing to form secondary cementitious material.

Effect of elapsed time after mixing on CBR for unsoaked condition.

The variation in CBR ratio with elapsed time after mixing for the various lime and IOT treatments for unsoaked condition is shown in Figure 14a,b for 0\% lime-up to 10\% IOT and optimal 8\% lime-up to $10 \%$ IOT treatment. The CBR values generally increased with elapsed time up to $2 \mathrm{~h}$, before decreasing at $3 \mathrm{~h}$ elapsed time irrespective of lime and IOT treatment. The reduction in the CBR values at $3 \mathrm{~h}$ elapsed time may be the link to the disruption of the hydration products in the process of compaction. The hydration product bound the soil particles, however, compaction after delay disrupted this aggregation, thereby resulting in lower densities and consequently lower strength. Nigerian General Specifications [34] endorse a CBR value of $180 \%$ for adequate cement stabilization in the laboratory. However, when compacted at 100\% West African Standard energy (intermediate compaction) with OMC, an unsoaked CBR value of $80 \%$ is desired for base course and 30\% CBR soaked value for sub-base course $[63,64]$. Based on the above criterion, the soil optimally treated with $8 \% 1 \mathrm{lime} / 8 \%$ IOT compacted with BSL energy recorded CBR values of $150 \%$ which met the requirement for base course material [34]. However, the least conventional CBR values for lime modified soils of 40, 80, 
and $100 \%$ (BSL) for subgrade; sub-base course and base course were used in assessing the strength of the soil-lime specimen.

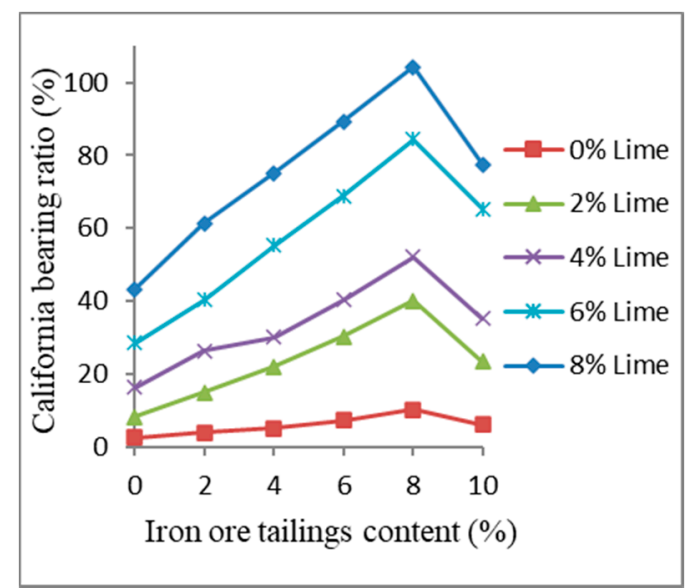

(a)

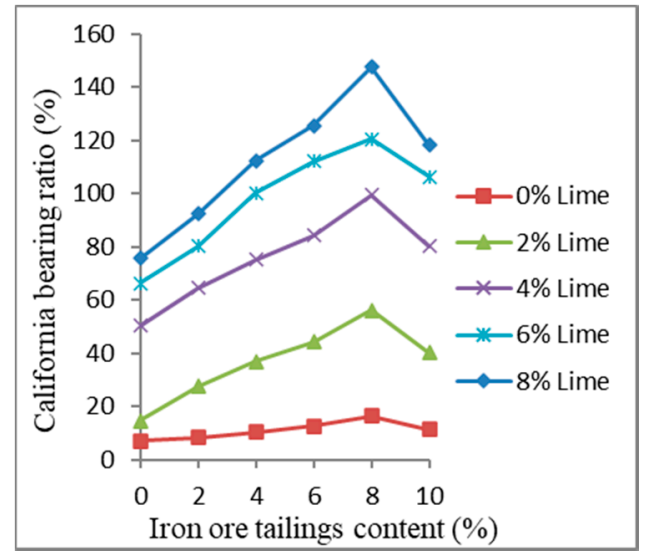

(c)

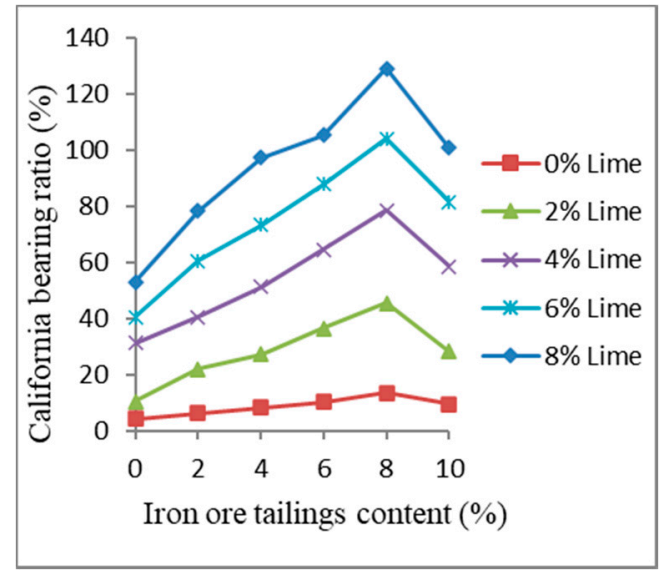

(b)

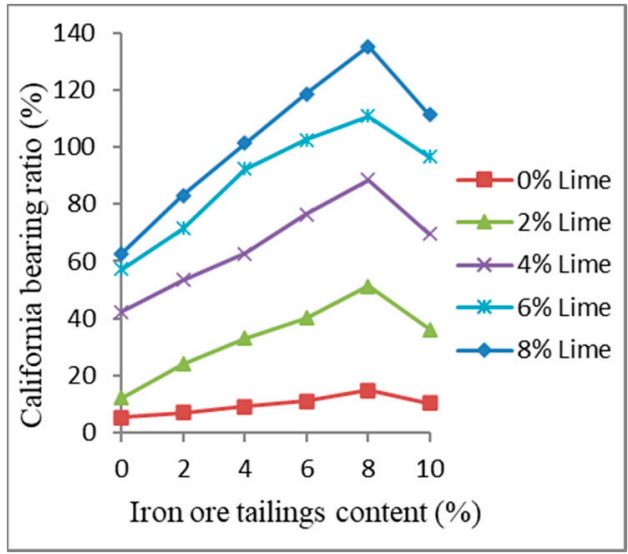

(d)

Figure 13. Variation of California bearing ratio (unsoaked condition) of BCS-lime mixtures with IOT content for different elapsed times after mixing: (a) $0 \mathrm{~h}$, (b) $1 \mathrm{~h}$, (c) $2 \mathrm{~h}$, (d) $3 \mathrm{~h}$.

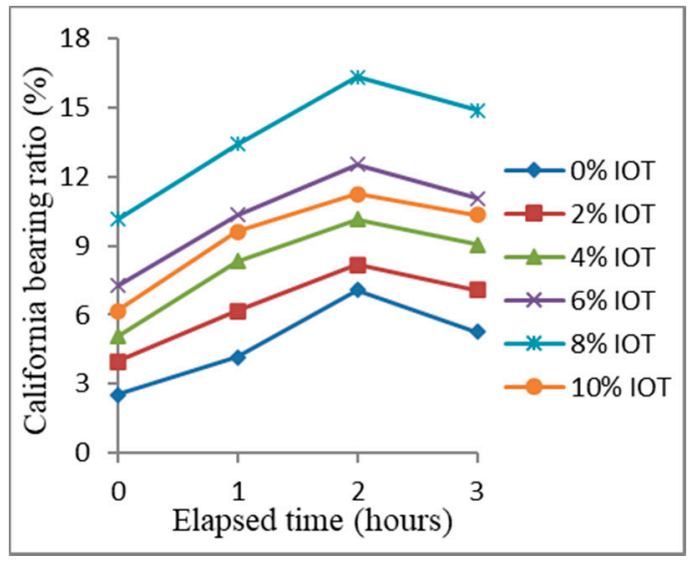

(a)

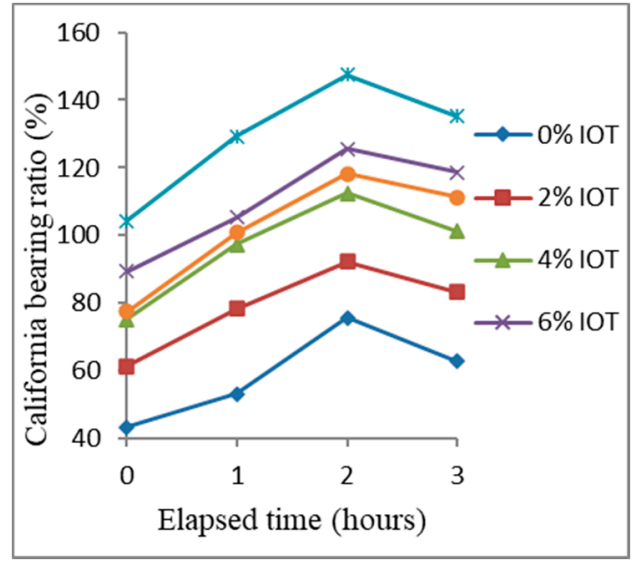

(b)

Figure 14. Variation of California bearing ratio of BCS with elapsed time after mixing for different treatments: (a) $0 \%$ lime-up to $10 \%$ IOT, (b) $8 \%$ lime-up to $10 \%$ IOT. 


\subsection{Regression Analysis}

The relationship between strength properties (i.e., UCS and CBR) established in Equations (4) and (5) indicates a strong link between UCS and CBR as dependent soils variables with lime content (L), iron ore tailing content (IOT), elapsed time (ET), liquid limit (LL), plasticity index (PI), maximum dry density (MDD), and optimum moisture content (OMC) as independent variables. The strength of the relationship is established by the coefficients of determination of $R^{2}=89.4 \%$ for UCS and $R^{2}=90.1 \%$ for CBR from Equations (4) and (5), respectively. From the equations, variables with positive coefficients increased the strength properties of the treated soil with increases in such variables. It was observed that only LL had a negative coefficient and was the only variable that had a negative impact on the strength of the treated soil. Thus, an increase in soil LL, which is related to increasing plasticity of the treated soil, affected the strength of the soil and is a requirement to be carefully monitored during the period of field compaction. It is commendable that the lime and IOT use in the soil improvement and the elapsed time after mixing significantly improved the strength properties considered (UCS and CBR), which equally agreed with laboratory results. Therefore, during field compaction, caution should be reserved to guarantee that adequate quantities of lime and IOT are added and mixed properly prior to compaction at a maximum delay period of $2 \mathrm{~h}$ so as to achieve desired compaction density in the field at optimum moisture content of optimal $8 \%$ lime $-8 \%$ IOT blend.

$$
\begin{aligned}
& \mathrm{UCS}=-9824+204 \mathrm{~L}+27.8 \mathrm{IOT}+130 \mathrm{ET}-2.8 \mathrm{LL}+57.6 \mathrm{PI}+5198 \mathrm{MDD}+13.3 \mathrm{OMC} \\
& R^{2}=89.4 \% \\
& \text { CBR }(\text { unsoaked })=-541+13.4 \mathrm{~L}+0.18 \mathrm{IOT}+10.7 \mathrm{ET}-1.18 \mathrm{LL}+2.81 \mathrm{PI}+321 \mathrm{MDD}+1.25 \mathrm{OMC} \\
& \quad R^{2}=90.1 \%
\end{aligned}
$$

where UCS = unconfined compressive strength $\left(\mathrm{kN} / \mathrm{m}^{2}\right) ; \mathrm{CBR}=$ California bearing ratio $(\%) ; \mathrm{L}=$ lime content (\%); IOT = iron ore tailing content (\%); ET = elapsed time (hours); LL = liquid limit (\%); PI = plasticity index $(\%) ; \mathrm{MDD}=$ maximum dry density $\left(\mathrm{Mg} / \mathrm{m}^{3}\right) ; \mathrm{OMC}=$ optimum moisture content $(\%)$.

\subsection{Microanalysis of Specimens}

Scanning Electron Microscope Images

Specimens cured for 7 days.

Scanning electron microscope (SEM) equipment was employed to investigate the morphology of the stabilized soil. Figure 15a,b shows the SEM results of the natural and optimal $8 \%$ lime- $8 \%$ IOT-treated BCS after a seven-day curing period. From the SEM images, the natural soil has a smooth surface appearance with macropores (see Figure 15a) while the optimally treated BCS, after seven days curing, was aggregated with coarse and rough textured surface appearance. The morphology may be related to new compounds formed as a result of aggregation of the soil particles due to cation exchange, flocculation-agglomeration, pozzolanic reaction, and carbonation that took place during the curing period. The micrograph showed the development of cementitious products of calcium silicates hydrates, calcium aluminate hydrates, and calcium aluminosilicate hydrates covering the soil grains and filling up interaggregate openings. These compounds were accountable for strength gain. Similar results were reported by Mallela et al. [65] as well as Deneele et al. [66]. 


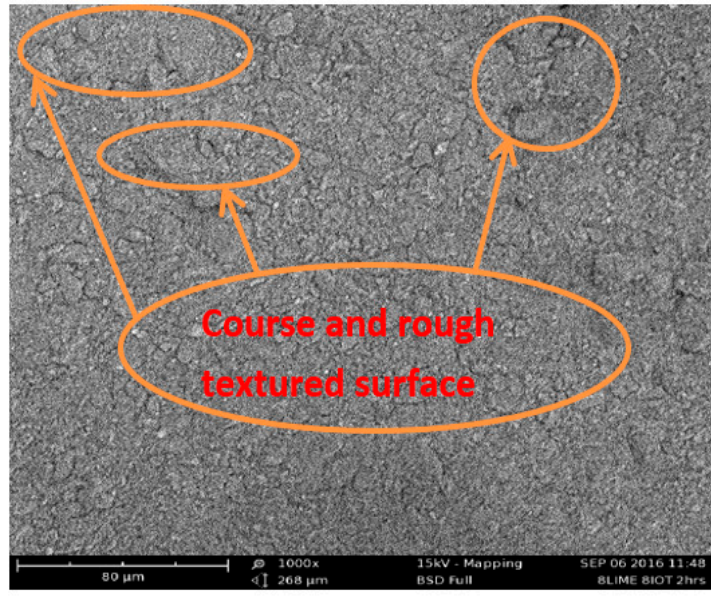

(a)

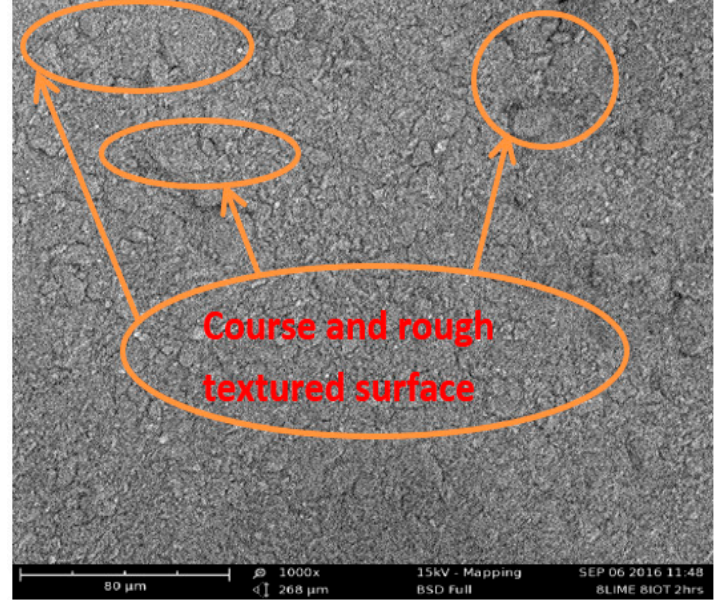

(b)

Figure 15. SEM images of: (a) natural BCS after 7 days curing at $\times 1000$ magnification, (b) optimal $8 \%$ lime $-8 \%$ IOT blend after 7 days curing at $\times 1000$ magnification.

\section{Conclusions}

The effect of elapsed time on the strength properties of lime- and IOT-treated BCS was studied. From the study, the following conclusions can be drawn:

1. An improvement in the plasticity of the treated soil with admixture and up to $2 \mathrm{~h}$ elapsed time after mixing was noted.

2. MDD increased while OMC decreased with increase in IOT content. The MDD value increased up to $2 \mathrm{~h}$ elapsed time after mixing for all the lime and IOT treatments considered and decreased at $3 \mathrm{~h}$ elapsed time after mixing. The OMC value decreased with increased elapsed time after mixing for all the lime and IOT treatments considered.

3. The UCS value increased with increase in both lime and IOT contents for up to $2 \mathrm{~h}$ elapsed time after mixing.

4. CBR improved with increase in lime and IOT contents up to $2 \mathrm{~h}$ elapsed time after mixing.

5. Regression analysis shows the strength of the affiliation between strength properties (UCS and CBR) and the soil variables by the coefficients of determination of $R^{2}=89.4 \%$ for UCS and $R^{2}=90.1 \%$ for CBR.

6. Based on the best recorded admixture improvement of the soil, the optimal treatment of $8 \%$ lime- $8 \%$ IOT for a maximum $2 \mathrm{~h}$ elapsed time after mixing is recommended for use as sub-base material for low-trafficked roads.

Author Contributions: A.Q.B.: investigation, methodology, resources, writing original draft preparation; E.A.O.: Conceptualization, supervision, project administration, writing review editing, resources; Y.P.: Software, Validation, formal analysis, writing review editing, resources; O.K.J.: Conceptualization, supervision, Project administration, writing review editing, resources. All authors have read and agreed to the published version of the manuscript.

Funding: This research received no external funding.

Conflicts of Interest: The authors declare no conflict of interest.

\section{References}

1. Osinubi, K.J.; Katte, V.Y. Effect of elapsed time after mixing on grain size and plasticity characteristic. I: Soil-lime mixes. Niger. Soc. Eng. Tech. Trans. 1997, 32, 65-77.

2. Okonkwo, U.N. Effects of Compaction Delay on the Properties of Cement-Bound Lateritic Soils. Niger. J. Technol. 2009, 28, 8-12.

3. Habeeb, A.Q.; Olabambo, A.A.; Bunshiya, G.B. Impact of Compaction Delay on the Engineering Properties of Cement Treated Soil. IOSR J. Mech. Civ. Eng. 2013, 4, 9-15. 
4. Ochepo, J.; Osinubi, K.J.; Sadeeq, J.A. Statistical Evaluation of the Effect of Elapse time on the Strength Properties of Lime-Bagasse Ash Treated Black Cotton Soil. Int. J. Eng. Res. Technol. 2013, 2, 1-18.

5. Mujedu, K.A.; Adebara, S.A.; Lamidi, I.O. Influence of Compaction Delay on Cement Stabilized Lateritic Soil. Int. Conf. Sci. Eng. Environ. Technol. 2016, 1,29-38.

6. Osuolale, O.M.; Olawuyi, O.A.; Busari, A.; Adewumi, A.S. Effect of Compaction Delay on the Strength of Cement Stabilised Lateritic Soil. Lautech. J. Eng. Technol. 2017, 11, 47-51.

7. Ola, S.A. The geotechnical properties of black cotton soils of North Eastern Nigeria. In Tropical Soils of Nigeria in Engineering Practice; Ola, S.A., Ed.; A.A. Balkema: Rotterdam, The Netherlands, 1983; Volume 26, pp. 15-24.

8. Meshida, E.A.; Oyekanmi, G.L.; Ogundalu, A.O. Effect of steel mill dust on the strength characteristics of Black cotton clay soils. Int. J. Sci. Eng. Res. 2013, 4, 2242-2246.

9. Amadi, A.A. Enhancing durability of quarry fines modified black cotton soil subgradewith cement kiln dust stabilization. Transp. Geotech. 2014, 1, 55-61. [CrossRef]

10. Hadi, A.A.; Lawal, S.; Mahmoud, H.A.; Zawami, D. Novel admixture for Improvement of foundation on tropical expansive soils. Int. J. Integr. Eng. 2017, 9, 44-49.

11. Diamond, S.; Kinter, E.B. Mechanisms of Lime Stabilization. Highw. Res. Rec. 1965, 92, 83.

12. Bell, F.G. Stabilization and treatment of clay soils with lime part 2-Some Applications. Ground Eng. 1988, 21, 25-29.

13. Bell, F.G. Lime Stabilization of Clay Minerals and Soils. Eng. Geol. 1996, 42, 223-237. [CrossRef]

14. Pei, X.; Zhang, F.; Wu, W.; Liang, S. Physicochemical and index properties of loess stabilized with lime and fly ash piles. Appl. Clay Sci. 2015, 114, 77-84. [CrossRef]

15. Etim, R.; O Eberemu, A.; Osinubi, K. Stabilization of black cotton soil with lime and iron ore tailings admixture. Transp. Geotech. 2017, 10, 85-95. [CrossRef]

16. Balogun, L.A. Effect of sand and salt additives on some geotechnical properties of lime stabilized black cotton soil. Niger. Eng. 1991, 26, 15-24.

17. Matawal, D.S.; Tomarin, O.I. Response of some tropical laterite to cement stabilization. Coll. Eng. Conf. Ser. Kaduna Polytech. 1996, 3, 90-95.

18. Shailendra, S.; Hemant, B.V. Stabilization of black cotton soil using lime. Int. J. Sci. Res. 2015, 4, $2090-2094$.

19. Vaibhav, R.D.; Shrikant, M.H. Assess Effects of IOT and lime on engineering properties of laterite. J. Raw Mater. Res. 2017, 25, 7.

20. Nadgouda, K.A.; Hegde, R.A. The effect of lime stabilization on properties of black cotton soil. In Proceedings of the Indian Geotechnical Conference, Mumbai, India, 16-18 December 2010.

21. Ramesh, H.N.; Krishnaiah, A.J.; Shilpa, S.S. Effect of lime on the index Properties of Black cotton soil and mine tailing mixtures. IQSR J. Eng. 2013, 3, 01-07. [CrossRef]

22. Amruta, A.B.; Lobhesh, N.M.; Kunal, R.R. Quality Assessment for Stabilization of Black cotton Soil by Using Lime. Int. J. Innov. Eng. Technol. 2015, 5, 49-53.

23. Sen, P.K.; Ghose, M.K. Sitting of Tailings Pond for Safe Disposal of Tailings from Iron-Ore Beneficiation plants-A case Study. Mine Technol. 1997, 18, 63-67.

24. Shivam, T.; Anubhav, R.; Bajpai, Y.K. Effect of Iron ore Tailings on the Flexural Strenght of Concrete. Int. J. Res. Appl. Sci. Eng. Technol. 2017, 5, 2773-2778.

25. Ajaka, E.O. Recovering fine iron minerals from Itakpe iron ore process tailing. ARPN J. Eng. Appl. Sci. 2009, 4, 17-28.

26. Pedro, D.D.; Guilherme, B.C.; Margarida, M.F.L.; Rosa, M.F.L. Characterisation and Magnetic concentration of and iron ore tailings. J. Mater. Res. Technol. 2019, 8, 1052-1059. [CrossRef]

27. Elinwa, A.U.; Maichibi, J.E. Evaluation of the Iron Ore Tailings from Itakpe in Nigeria as Concrete Material. Adv. Mater. 2014, 3, 27-32. [CrossRef]

28. Pebble Project. Tailings and Tailings Managements; Northern Dynasty Mines Inc.: Vancouver, BC, Canada, 2005; pp. 1-4.

29. Ishola, K. Modification of Lateritic Soil with Iron Ore Tailing. Master's Thesis, Civil Engineering Department, Ahmadu Bello University, Zaria, Nigeria, 2014. Unpublished.

30. Samadou, J. Stabilization of Black Cotton Soil with Iron-Ore Tailing. Master's Thesis, Department of Civil Engineering, Ahmadu Bello University, Zaria, Nigeria, 2015. Unpublished. 
31. Etim, R.K.; Eberemu, A.O.; Osinubi, K.J. Effect of lime-iron ore tailing blend on the expansive behavior of black cotton soil. In Proceedings of the 2014 Nigerian Engineering Conference, Engineering and Technology for Economic Transformation, Ahmadu Bello University, Zaria, Nigeria, 15-18 September 2014; [CD-ROM]; Faculty of Engineering Publication, Ahmadu Bello University: Zaria, Nigeria, 2014; pp. 864-872, Section 6.

32. British Standard (BS) 1377. Methods of Testing Soils for Civil Engineering Purposes; British Standard Institution: London, UK, 1990.

33. British Standard (BS) 1924. Methods of Tests for Stabilized Soils; British Standard Institute: London, UK, 1990.

34. Nigerian General Specifications. Roads and Bridges; Federal Ministry of Works: Abuja, Nigeria, 1997.

35. American Society of Testing and Materials (ASTM). Annual Book of Standards; American Society of Testing and Materials: Philadelphia, PA, USA, 1992; Volume 04.08.

36. American Association of State Highway and Transportation Officials (AASHTO). Standard Specification for Transport Materials and Method Sampling and Testing, 14th ed.; AASHTO: Washington, DC, USA, 1986.

37. Osinubi, K.J.; Yohanna, P.; Eberemu, A.O. Cement Modification of Tropical Black Clay Using Iron Ore Tailing as Admixture. J. Transp. Geotech. 2015, 15, 35-49. [CrossRef]

38. Bernard, O.U. Effect of Locust Bean Waste Ash on Lime Modified Black Cotton Soil. Master's Thesis, Department of Civil Engineering, Ahmadu Bello University, Zaria, Nigeria, 2011. Unpublished.

39. Osinubi, K.J. Lime modification of black cotton soils. Spectr. J. 1995, 2, 112-122.

40. Nelson, J.D.; Miller, D.J. Expansive Soils, Problems and Practice in Foundation and Pavement Engineering; Wiley: New York, NY, USA, 1992.

41. Lawton, E.C. Soil Improvement and Stabilization: Section 5A: Nongrouting Techniques. In Practical Foundation Engineering Handbook; Brown, R.W., Ed.; McGraw Hill: New York, NY, USA, 1996; pp. 5.3-5.276.

42. Suits, L.D.; Sheahan, T.; Feng, T.-W. Effects of Small Cement Content on Consolidation Behavior of a Lacustrine Clay. Geotech. Test. J. 2002, 25, 53. [CrossRef]

43. Al-Rawas, A.A.; Taha, R.; Nelson, J.D.; Beit Al-Shab, T.; Al-Siyabi, H. A Comparative Evaluation of Various Additives Used in the Stabilization of ExpansiveSoils. Geotech. Test. J. 2002, 25, 199-209.

44. Phani, K.B.R.; Sharma, R.S. Effect of fly ash on engineering properties of expansive soils. J. Geotech. Geoenviron. Eng. 2004, 130, 764-767. [CrossRef]

45. Ochepo, J. Effect of Elapsed Time on the Geotechnical Properties of Lime-Bagasse Ash Stabilized Black Cotton Soil. Master's Thesis, Civil Engineering Department, Ahmadu Bello University, Zaria, Nigeria, 2008. Unpublished.

46. Amadi, A.A. Evaluation of changes in index properties of lateritic soil stabilized withFly ash. Leonard Electron. J. Pract. Technol. 2010, 9, 69-78.

47. Alhassan, M. Effect of Bagasse Ash on Modified Laterite. Master's Thesis, Civil Engineering Department, Ahmadu Bello University, Zaria, Nigeria, 2006. Unpublished.

48. Abdullahi, M.M. The Effect of Elapsed Time after Mixing on the Properties of Cement- Locust Bean Waste Ash Modified Lateritic Soil. Master's Thesis, Department of Civil Engineering, Ahmadu Bello University, Zaria, Nigeria, 2011. Unpublished.

49. Mustapha, A.M. Effect of Bagasse Ash on Cement Stabilized Laterite. Master's Thesis, Ahmadu Bello University, Zaria, Nigeria, 2006. Unpublished.

50. Nwadiogbu, C.P. The Effect of Elapsed Time on Lateritic Soil Modified with Lime and Locust Bean Ash. Master's Thesis, Department of Civil Engineering, Ahmadu Bello University, Zaria, Nigeria, 2012. Unpublished.

51. Yisa, G.L. Stabilization of Lateritic Soil with Iron-Ore Tailing. Master's Thesis, Department of Civil Engineering, Ahmadu Bello University, Zaria, Nigeria, 2014. Unpublished.

52. Eberemu, A.O.; Abdullahi, M.M.; Osinubi, K.J. Influence of Delay after Mixing on Compaction Characteristics of Cement-Locust Bean Waste Ash Modified Lateritic soil. J. Appl. Sci. Eng. Technol. 2015, 15, 1-7.

53. Moses, G. Stabilization of black cotton soil with Ordinary Portland Cement Using Bagasse ash as admixture. IRJI J. Res. Eng. 2008, 5, 107-115.

54. Oriola, F.; Moses, G. Groundnut Shell Ash Stabilization of Black Cotton Soil. Electron. J. Geotech. Eng. 2010, 15, 415-428.

55. Osinubi, K.J.; Eberemu, A.; Yohanna, O.P.; Etim, R.K. Reliability Estimate of the Compaction Characteristics of Iron Ore Tailings Treated Tropical Black Clay as Roads Pavement Sub-Base Material. In Proceedings of the Geo-Chicago, Chicago, IL, USA, 14-18 August 2016. 
56. Osinubi, K.J. Influence of compactive efforts and compaction delays on lime-treated soil. J. Transp. Eng. 1998, 124, 149-155. [CrossRef]

57. Moses, G.; Saminu, A.; Oriola, F.O.P. Influence of Compactive Efforts on compacted Foundry Sand Treated with Cement Kiln Dust. Civ. Environ. Res. 2012, 2, 11-24.

58. Ingles, O.G.; Metcalf, J.B. Soil Stabilization Principles and Practice; Butterworths: Sydney, Australia, 1972.

59. Negi, S.S.; Gupta, M.K.; Sharma, S.D. Sequestered organic carbon pool in the forest Soils of Uttarakh and State, India. Int. J. Sci. Environ. Technol. 2013, 2, 510-520.

60. Mitchell, J.K.; Hooper, D.R. Influence of time between mixing and compaction on properties of lime stabilized expansive clay. Highw. Res. Board Bull. 1961, 304, 14-31.

61. Tamer, Y.E. The effect of curing conditions on the unconfined compression strength of Lime treated expansive soils. J. Road Mater. Pavement Des. 2016, 17, 52-69.

62. Osinubi, K.J.; Eberemu, A.O.; Aliu, O.S. Stabilization of laterite with cementand bagasse ash admixture. In Proceedings of the First International Conference on Environmental Research echn. And Policy "ERTEP 2007" under the Auspices of International Society of Environmental Geotechnology, Accra, Ghana, 16-19 July 2007.

63. Gidigasu, M.D.; Dogbey, J.L.K. Geotechnical characterization of laterized Decomposed rocks for pavement construction in dry sub-humid environment. In Proceedings of the 6th South East Asian Conference on Soil Engineering, Taipei, Taiwan, 19-23 May 1980; Volume 1, pp. 493-506.

64. Osinubi, K.J. Laboratory trial of soil stabilization of Nigerian black cotton soils. Niger. Soc. Eng. Tech. Trans. 2000, 35, 13-21.

65. Mallela, J.; Quintus, P.E.; Smith, K.L. Consideration of Lime-Stabilized Layers in Mechanistic-Empirical Pavement Design. 2004. Available online: http://www.training.ce (accessed on 24 January 2006).

66. Deneele, D.; Cuisinier, O.; Hallaire, V. Micostructural evolution and physico-chemical and behavior of compacted clayey soil submitted to an alkaline plume. J. Rock Mech. Geotech. Eng. 2010, 2, 169-177. [CrossRef]

Publisher's Note: MDPI stays neutral with regard to jurisdictional claims in published maps and institutional affiliations.

(C) 2020 by the authors. Licensee MDPI, Basel, Switzerland. This article is an open access article distributed under the terms and conditions of the Creative Commons Attribution (CC BY) license (http://creativecommons.org/licenses/by/4.0/). 